University for Business and Technology in Kosovo

UBT Knowledge Center

$7-2018$

\title{
SISTEMI MENAXHUES I TRAFIKUT URBAN NË KOHË REALE NË KOMUNËN E PRISHTINËS
}

Armir Kuçi

University for Business and Technology - UBT

Follow this and additional works at: https://knowledgecenter.ubt-uni.net/etd

Part of the Computer Sciences Commons

\section{Recommended Citation}

Kuçi, Armir, "SISTEMI MENAXHUES I TRAFIKUT URBAN NË KOHË REALE NË KOMUNËN E PRISHTINËS" (2018). Theses and Dissertations. 2.

https://knowledgecenter.ubt-uni.net/etd/2

This Thesis is brought to you for free and open access by the Student Work at UBT Knowledge Center. It has been accepted for inclusion in Theses and Dissertations by an authorized administrator of UBT Knowledge Center. For more information, please contact knowledge.center@ubt-uni.net. 


\section{(11T) \\ ( )}

Universiteti për Biznes dhe Teknologji

Fakulteti i Shkencave Kompjuterike dhe Inxhinieri KOMUNËN E PRISHTINËS

Niveli Master

Armir Kuçi

Korrik/2018

Prishtinë 
Universiteti për Biznes dhe Teknologji

Fakulteti i Shkencave Kompjuterike dhe Inxhinieri

Punim Diplome

Viti Akademik 2014 - 2015

\title{
SISTEMI MENAXHUES I TRAFIKUT URBAN NË KOHË REALE NË
} KOMUNËN E PRISHTINËS

\author{
Mentori: Prof.Dr. Zhilbert Tafa
}

Studenti: Armir Kuçi

Korrik/2018

Ky punim është përgatitur dhe dorëzuar si pjesë e planprogramit të studimeve Master 


\section{FALENDERIM}

Gjithmonë arritjet shoqërohen me shumë njerëz të cilët qëndrojnë prapa, duke duartrokitur suksesin. Prandaj falënderimi ndaj tyre është gjithnjë i mirëseardhur.

Gjithë kjo punë e imja nuk do të ishte realizuar në radhë të parë pa ndihmën e mentorit tim Prof. Dr. Zhilbert Tafa, i cili ishte i gatshëm në çdo kohë që të më ndihmoj dhe këshilloj rreth gjithçkaje që kam paraqitur sot para jush.

Por, sot nuk do t'ia kisha dalë mbanë as pa ndihmën e familjes sime e veçanërisht të vëllait Msc. Driton Kuçi. Shpreh mirënjohjen time për besimin që patën tek unë, mbështetjen dhe ndihmën që më dhanë. Një falënderim special i dedikohet babait tim të ndjerë, i cili gjatë gjithë jetës së tij nuk pushoi së punuari që sukseset e mia të mos mungojnë.

Gjithashtu do të doja të falënderoja kolegët e mi Gazmend Gashin, Ramiz Krasniqin dhe Vilzan Arifajn në Departamentin e Shkencave Kompjuterike dhe Inxhinieri, prej të cilëve kam mësuar shumë. 


\section{ABSTRAKTI}

Duke marrë parasysh vonesat e shpeshta të autobusëve të transportit publik në qytetin e Prishtinës, të cilat paraqesin një shqetësim të madh për qytetarët, është konceptuar, dizajnuar, realizuar dhe demostruar një sistem informues për qytetarët dhe menaxhues për Qendrën Menaxhuese të Transportit Publik mbi gjendjen reale të autobusëve në teren. Ky punim shkencor, paraqet një zgjidhje të Internet of Things (IoT) për përmirësimin e transportit publik. Qëllimi i këtij sistemi është informimi i qytetarëve në kohë reale për arritjen e autobusëve në stacionet përkatëse si dhe të bëjë transportin publik më lehtë të menaxhueshëm në qytetin e Prishtinës. Përfituesit direkt të këtij sistemi janë qytetarët dhe komuna e Prishtinës, kurse përfituesit indirekt janë kompanitë për menaxhimin e transportit publik. Ky sistem lehtë mund të përdoret edhe në qytetet tjera të Kosovës. Përmes GPS pranuesit bëhet përcaktimi i pozicioneve të autobusëve dhe GSM modulit transmetimi i pozicioneve të tyre në Server (Qendrën Menaxhuese). Përdoruesit përmes Internetit duke përdorur një web shfletues (browser) informohen në kohë reale arritjen e autobusëve në stacionet përkatëse në bazë të gjendjes reale të trafikut.

Testimi i sistemit është bërë në disa linja të transportit publik në qytetit e Prishtinës. Përcaktimi i pozicionit të autobusëve është bërë përmes smartphonëve, të cilët zëvendësojnë GPS pranuesit e vërtetë dhe mundësojnë transmetimin e këtyre pozicioneve tek Qendra Menaxhuese.

Rezultatet e arritura gjatë testeve dëshmojnë se sistemi përmbush qëllimin kryesor të sistemit, informimin e qytetareve në kohë reale për transportin publik si dhe vonesat e mundshme. 


\section{PËRMBAJTJA}

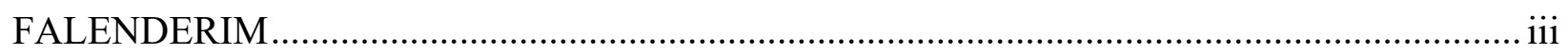

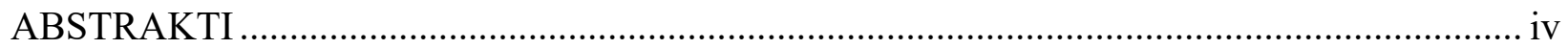

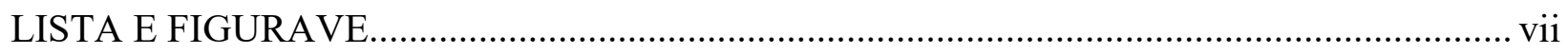

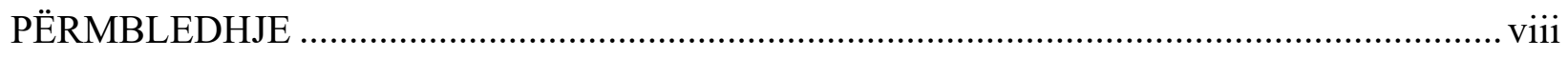

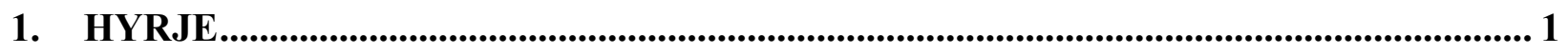

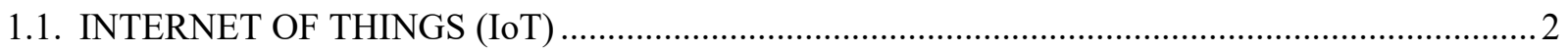

1.2. DEFINIMI I PROBLEMIT - PYETJET HULUMTUESE …………………………………..........

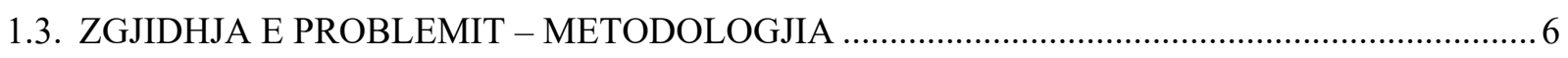

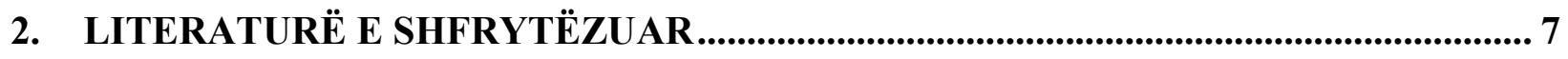

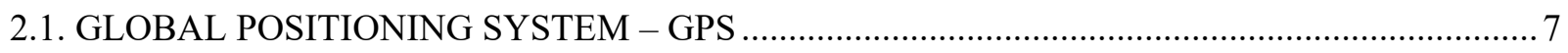

2.2. GLOBAL SYSTEM FOR MOBILE COMMUNICATION - GSM ……………………………....

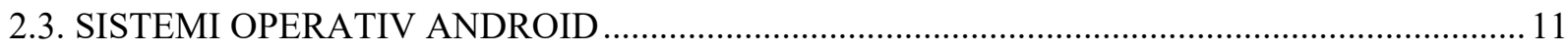

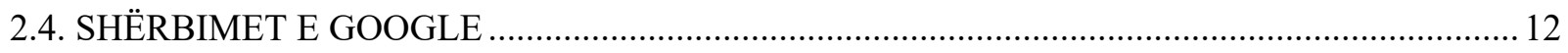

2.5. SISTEME DHE HULUMTIME TË NGJAJSHME NGA LITERATURA DHE PRAKTIKA........ 14

3. KOMPONENTËT E SISTEMIT_.............................................................................................. 19

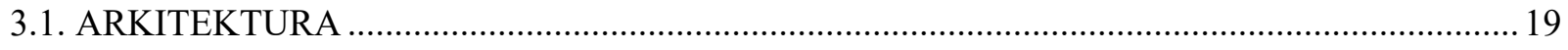

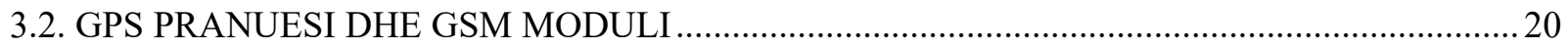

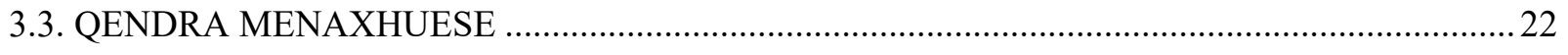

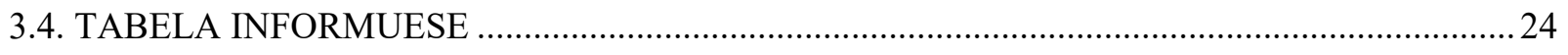




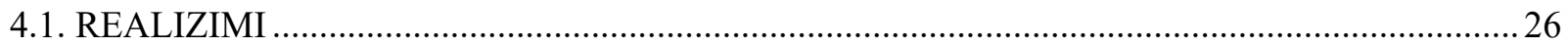

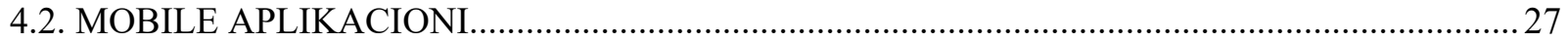

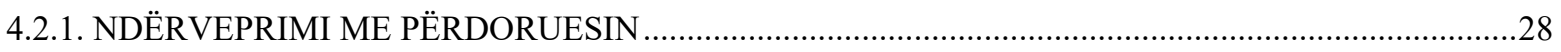

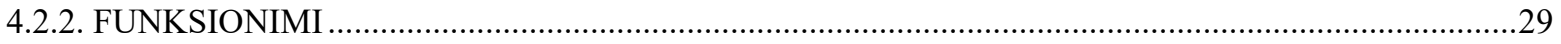

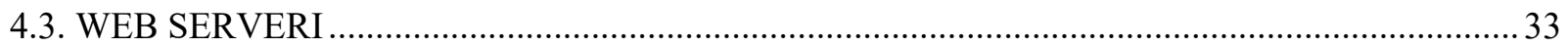

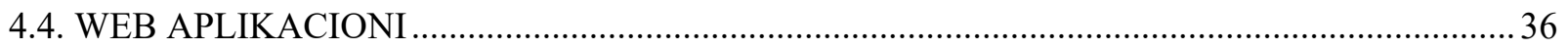

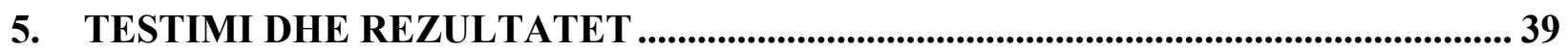

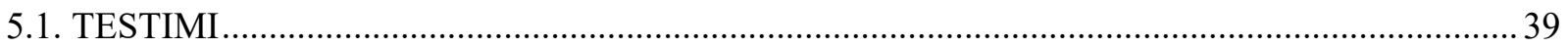

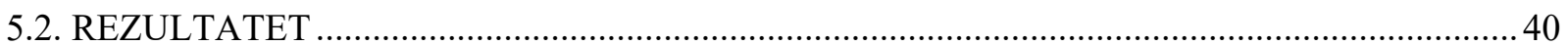

6. KONKLUZIONET DHE MUNDËSITË............................................................................. 42

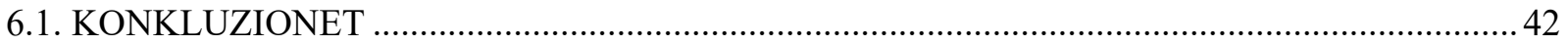

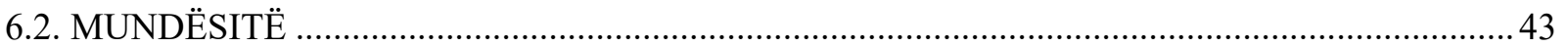

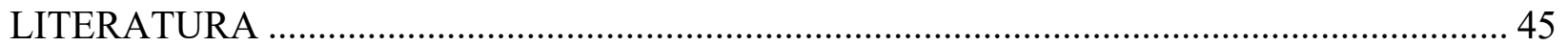




\section{LISTA E FIGURAVE}

Figura 1.1. Identifikimi i pajisjeve të ndryshme përmes IoT-së. ............................................. 1

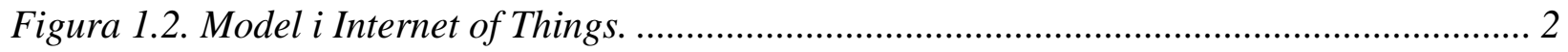

Figura 1.3. E ardhmja e IoT-së. .......................................................................................... 3

Figura 1.4. Disa aplikacione bazuar në IoT....................................................................... 4

Figura 1.5. Stacionet e autobusëve në qytetin e Prishtinës. ........................................................ 5

Figura 2.1. Parimi i funksionimit të GPS. ........................................................................ 8

Figura 2.2. Metodat e sistemit të përcaktimit të trajektores lëvizëse së automjeteve................... 16

Figura 3.1. Arkitektura e Sistemit Menaxhues të Trafikut Urban. ............................................. 19

Figura 3.2. NMEA mesazh.............................................................................................. 20

Figura 3.3. Rrjedha e të dhënave për Qendrën Menaxhuese. ................................................... 22

Figura 3.4. Rrjedha e të dhënave për tabelën informuese ......................................................... 24

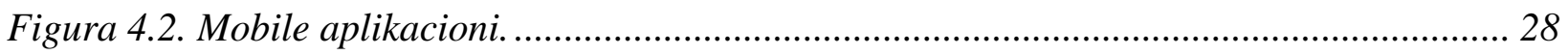

Figura 4.3. Mesazhi për aktivizimin e GPS. ........................................................................... 29

Figura 4.4. GPS Koordinatat e paraqitura në ekran................................................................ 30

Figura 4.5. Fajllat tekstual me koordinata të ruajtura në telefon të mençur. .............................. 31

Figura 4.6. Koordinatat (Latitude, Longitude, Altitude) të ruajtura në fajll.............................. 31

Figura 4.7. Mesazhi për të mbyllur mobile aplikacionin........................................................... 32

Figura 4.8. Baza e të dhënave me tabela................................................................................. 33

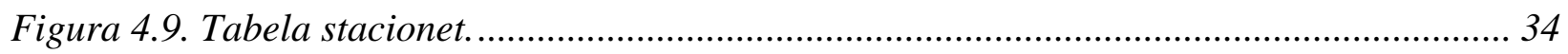

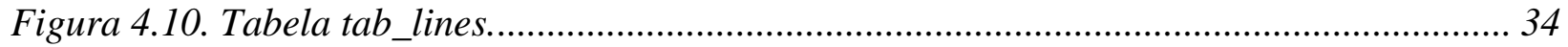

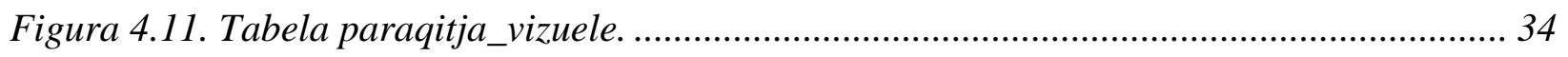

Figura 4.12. Tabela coordinate_bus. .................................................................................... 35

Figura 4.13.Tabela actualdistance ...................................................................................... 35

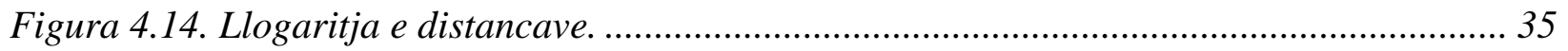

Figura 4.15. Harta e qytetit të Prishtinës. ............................................................................. 36

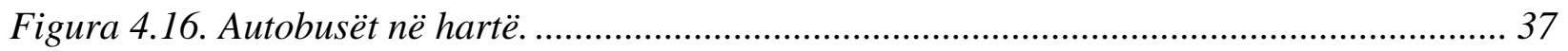

Figura 4.17. Emrat e stacioneve në hartë............................................................................. 37

Figura 4.18. ID e busit, linjës, stacioni i ardhshëm dhe koha e arritjes në stacion së autobusit. 37

Figura 4.19. Tabela informuese për stacionin 42................................................................. 38

Figura 4.20. Tabela informuese për stacionin 3................................................................. 38

Figura 5.1. Linja 1,4,5 të paraqitur në hartë (të dalluara me ngjyra). ...................................... 39

Figura 5.2. Koordinata të përcaktuara nga GPS pranuesi. ...................................................... 40

Figura 5.3. Paraqitja vizuale e pozicioneve në kohë reale të autobusëve në hartë................... 40

Figura 5.4. Gabime në hartat e Google ............................................................................... 41

Figura 5.5. Devijimi i GPS pranuesit në telefon të mençur...................................................... 41

Figura 6.1. Distanca kohore nga shërbimi i Google The distance matrix API.......................... 44 


\section{PËRMBLEDHJE}

Ky punim shkencor është përmbledhur në gjashtë kapituj, siç janë përshkruar më poshtë:

Kapitulli i parë përshkruan analizën e problemit dhe zgjidhjen e tij, pyetjet hulumtuese dhe metodologjinë.

Kapitulli i dytë përshkruan literaturën e shfrytëzuar, në përgjithësi sistemet dhe shërbimet e tjera që janë përdorur për të krijuar sistemin menaxhues siç janë GPS, Android/Google, GSM/GPRS, dhe sistemi për përcaktimin e trajektores lëvizëse të automjeteve.

Kapitulli i tretë paraqet dhe specifikon sistemin në tërësi dhe komponentët e tij.

Kapitulli i katërt përshkruan web-serverin dhe databazën si dhe implementimin e mobile aplikacionit në Android dhe web aplikacioneve për menaxhimin e sistemit në tërësi dhe tabelës informuese.

Kapitulli i pestë demostron dhe paraqet rezultatet e arritura të sistemit.

Kapitulli i gjashtë përmban konkluzionet, sfidat, mangësitë, mundësitë dhe sugjerimet për zhvillimin e sistemit në të ardhmen. 


\section{HYRJE}

Në ditët e sotme, shkencëtarët dhe zhvilluesit janë përqendruar në zhvillimin e paisjeve të ndryshme inteligjente që lejojnë përdoruesit për të kontrolluar dhe monitoruar ndryshimet e identifikimit të lokacionit të automjeteve, si dhe përcjelljen e trajektores lëvizëse në kohë reale. Zhvillimi në fusha të ndryshme të teknologjisë po bën të mundur që objektet inteligjente të jenë të afta për të identifikuar, përcaktuar vendndodhjen dhe për të komunikuar duke dërguar kështu në forma të reja të komunikimit midis njerëzve dhe paisjeve, gjithashtu ndërmjet paisjeve mes vete. Kur këto lloj paisjesh inteligjente do të bëhen më të zakonshme, do të rritet nevoja për strategji të rrjeteve në komunikacion e cila do të mundësojë që të gjitha të dhënat dhe paisjet e mençura të arrihen në çdo kohë dhe nga çdo vend. Internet of Things do të jetë një pjesë e rëndësishme e Internetit të së ardhmes (Internet of Future) dhe përmes valëve elektromagnetike do të mundësojë që objektet të identifikohen në mënyrë unike, për të përcaktuar vendndodhjen e tyre, të lidhen dhe të komunikojnë, siç shihet në figurën e mëposhtme.

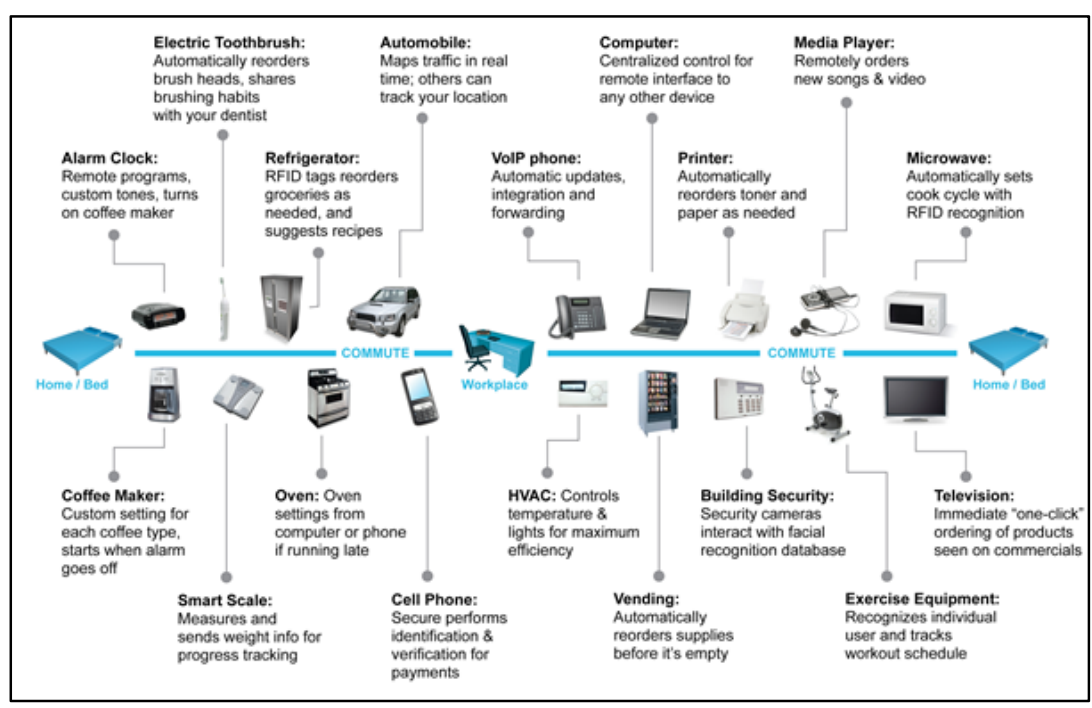

Figura 1.1. Identifikimi i pajisjeve të ndryshme përmes IoT-së. 


\subsection{INTERNET OF THINGS (IoT)}

Internet of Things është faza e tretë e revolucionit të Internetit. Pasi që dy fazat e para, World Wide Web gjatë viteve '90 dhe Interneti gjatë viteve '2000 kanë ndryshuar mënyrën se si njerëzit komunikojnë me njëri-tjetrin dhe ka ndryshuar mënyrën se si janë shpërndarë shërbimet. Ka shumë parashikime që IoT do të ndihmojë në zhvillimin ekonomik dhe aftësinë e sektorëve të tjerë. IoT i referohet një bote ku objektet dhe qeniet fizike, ashtu si të dhënat dhe mjediset virtuale, të githa ndërveprojnë me njëri-tjetrin në të njëjtën hapësirë dhe kohë. Një model të IoT-së është paraqitur te figura 1.2 [8].

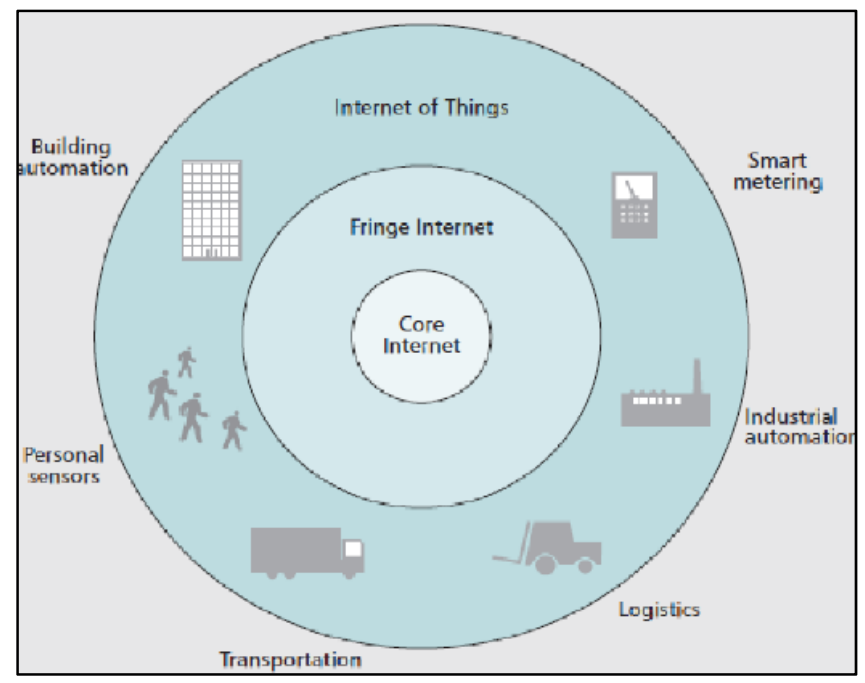

Figura 1.2. Model i Internet of Things.

Të dhënat e raportuara në raportin e ITU (International Telecommunications Unit), tregohet se mbi 2.7 miliardë njerëz po e përdorin Internetin ose $39 \%$ e popullsisë në botë ka pothuajse aq telefona të mençur të regjistruar sa ka njerëz në botë, 1.16 miliardë telefona të mençur që mundësojnë Internetin, 750 milionë banesa ose $41 \%$ e banesave në botë janë të lidhura me Internetin. Me lëvizjen e rrjeteve të PC-ve drejt rrjetit të objekteve, llogaritet që në 2020 që 50-100 miliardë paisje do të jenë të lidhura me Internetin [8]. 
Në rast se kjo llogaritje do të përfshijë jo vetëm komunikimin makinë-me-makinë por të githë komunikimin mes objekteve ky numër do të jetë më i lartë se 100 miliardë. Në 2020, trafiku i përdorimit të Internetit do të jetë 30 herë më i madh në krahasim me 2010 [7].

Fushat kryesore të hulumtimit që lidhen me zhvillimin e IoT janë: njohuritë IoT, aplikimet, kërkesat teknike dhe sfidat e biznesit. Disa nga aplikimet e mundshme të bazuara mbi IoT do të jenë ndërtesat që menaxhojnë përdorimin e tyre të energjisë, shtëpitë e mençura që kontrollojnë temperaturën dhe urat që kontrollojnë parametrat teknikë, makinat që gjejnë shtegun e trafikut dhe shumë të tjera (shih figurën 1.3.) [8].

E ardhmja e IoT-së varet nga zhvillimi i teknologjive të reja. Zhvillimi i plotë i IoT-së do të varet nga identifikimi i sfidave teknike dhe sfidave të tjera të tilla si: standardizimi, privatësia dhe çështjet socio-etike [7].

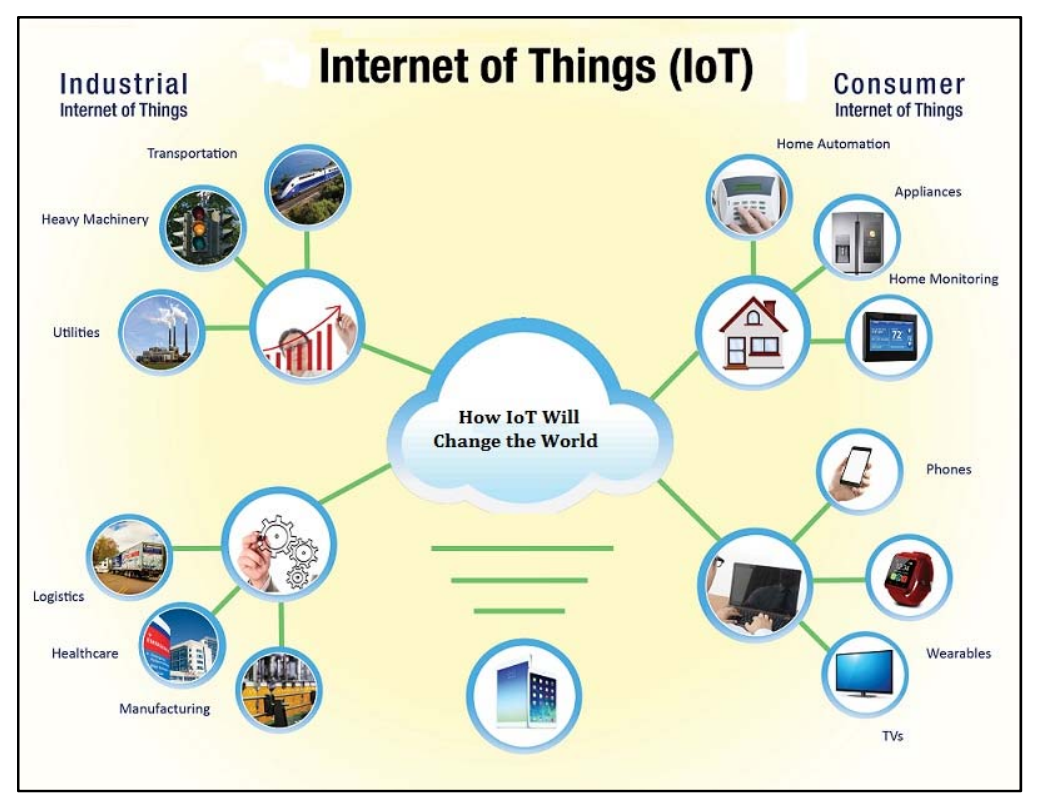

Figura 1.3. E ardhmja e IoT-së. 
IoT do të jetë një pjesë e rëndësishme e Internetit të së ardhmes (Internet of Future), dhe transmetuesit RFID do të mundësojnë objektet të identifikohen në mënyrë unike, të përcaktohet vendndodhja e tyre, të ndjejnë ndryshimet në të dhënat fizike dhe të lidhen dhe të komunikojnë [7].

Shumë aplikacione (Shiko figurën 1.2.) të bazuara mbi tiparet IoT-së janë zhvilluar dhe vendosur, disa prej këtyre janë: Smart Houses, Smart Cars, Google Glass, Smart Cities etj.

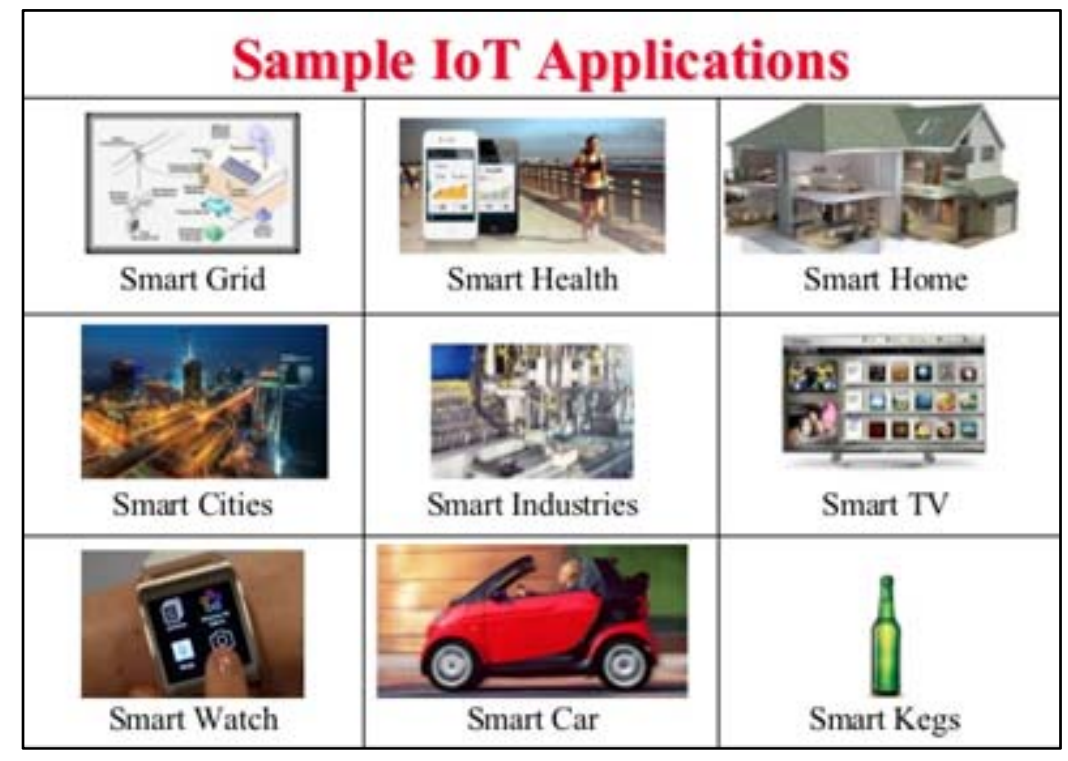

Figura 1.4. Disa aplikacione bazuar në IoT.

Aplikimet e IoT-së formojnë një hapësirë të gjerë të projektimit me shumë dimensione që përfshijnë vendosjen, lëvizjen, koston, madhësinë, burimet, komunikimin elektromagnetik, radio frekuencave, infrastrukturës, rrjetit, lidhjes dhe madhësisë së rrjetit [8]. 


\subsection{DEFINIMI I PROBLEMIT - PYETJET HULUMTUESE}

Në qytetin e Prishtinës, stacionet e autobusëve akoma janë pa tabela informuese (shih figurën 1.3.) për linjat e trafikut urban, ku, nëse përdorim atë, nuk kemi asnjë informacion për nisjet apo arritjet e autobusëve në stacione. Problemet kryesore mbeten vonesat e shpeshta të transportit urban, që kanë paraqitur probleme të mëdha tek qytetarët sidomos tek ata që janë në shkollë dhe tek ata që punojnë, të cilët nuk kanë arritur në vendin e duhur në kohë. Shumë qytetarë janë detyruar të telefonojnë në qendrën e autobusëve për të marrë informacione për nisjen ose arritjen e autobusëve në stacione, apo edhe vendndodhjen e tyre. Nëse do të funksiononte një sistem informues i autobusëve në kohë reale, do t'u lehtësonte qytetarëve udhëtimin dhe ata do ta menaxhonin më mirë kohën, e poashtu do të bëhej monitorimi më i lehtë i autobusëve në teren.

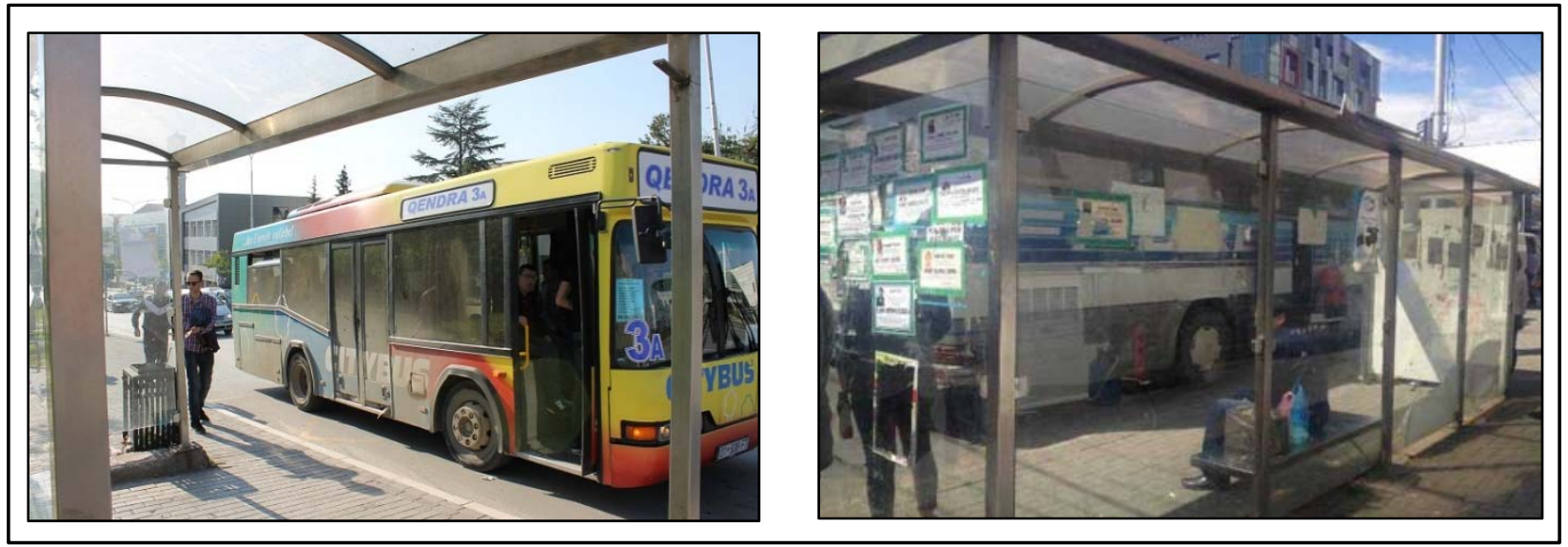

Figura 1.5. Stacionet e autobusëve në qytetin e Prishtinës.

Objekti i hulumtimit mund të definohet si në vijim:

Realizimi i sistemit menaxhues të trafikut urban në kohë reale në qytetin e Prishtinës.

Testimi i këtij sistemi në praktikë.

Analizë e mundësisë së implementimit të këtij sistemi në tërë shtetin e Kosovës. 


\subsection{ZGJIDHJA E PROBLEMIT - METODOLOGJIA}

Komuna e Prishtinës mund ta ketë një transport urban modern. Duke ditur që jetojmë në një kohë që jeta është shumë dinamike, shërbimet duhet të jenë më të shpejta dhe në kohë reale.

Përmes këtij sistemi menaxhues të trafikut urban sigurohen informacionet për autobusët në kohë reale, nga nisja e tyre deri në destinacion. Sistemi i pranon informacionet përmes GPS pranuesit që është i vendosur në autobus. Fillimisht GPS pranon sinjalet nga satelitët dhe pastaj përcakton vendndodhjen e autobusit, gjegjësisht gjerësinë dhe gjatësinë gjeografike si dhe lartësinë mbidetare.

Këto koordinata përmes GSM modulit transmetohen në Qendrën Menaxhuese ku bëhet ruajtja e pozicioneve dhe llogaritja e kohës së arritjes së autobusëve në stacionet përkatëse, e pastaj paraqitet koha e saktë e arritjes së autobusit në stacione në tabelën informuese. Vendosja e tabelave informuese në stacione të transportit urban, do të ndihmonte qytetarët për t'u informuar në kohë reale për udhëtimet e tyre.

Përmes këtij sistemi synohet:

- Monitorimi në kohë reale i transportit publik nga Komuna e Prishtinës, në mënyrë vizuale,

- Shfaqja e linjave dhe stacioneve në mënyrë vizuale për Qendrën Menaxhuese,

- Informim i saktë i qytetarëve në stacionet përkatëse,

- Të arrihen orare dhe planifikime efikase kohore dhe orare të besueshme.

Në këtë punim shkencor është përdorë metoda eksperimentale, konkretisht, funksionaliteti i sistemit është testuar në kushte reale, duke përdorur pajisje reale të qasshme. 


\section{LITERATURË E SHFRYTËZUAR}

\subsection{GLOBAL POSITIONING SYSTEM - GPS}

Sistemi i Pozicionimit Global (GPS) është sistem hapësinor radio pozicionimi. Në dekada, GPS është rritur duke ofruar përmirësim të Pozicionimit, Navigimit dhe Kohës (PNT). Si një sistem universal pozicionimi, GPS ka disa karakteristika të dobishme për disa lloje shërbimesh për përcaktimin e saktë (3-dimensional) të: Pozicionit, Shpejtësisë dhe Kohës (Position Velocity Time - PVT). Në ditët e sotme, GPS ofron mbulim global dhe atë 24 orë në ditë. Ai është në pronësi dhe operim nga qeveria e SH.B.A-ve. Shërbimi GPS është një drejtimësh broadcast (si radio FM), me numër të palimituar përdoruesish.

Qasja në GPS sinjalet civile është pa pagesë për përdoruesit dhe dokumentimi i domain-it publik i këtyre sinjaleve është në dispozicion të përdoruesve dhe industrisë, prandaj çdokush mund të zhvillojë pajisjet GPS. Tri pjesët kryesore përbërëse të GPS janë: komponentët hapsinorë (satelitët), komponentët kontrollues dhe menaxhues (Qendrat Menaxhuese të shpërndara nëpër botë), si dhe komponenti i përdoruesit (i cili mundëson përcaktimin e pozicionit) [19].

Parimi i funksionimit të sistemit GPS bazohet në një metodë të pozicionimit sferik e cila bëhet me matjen e kohës që i duhet sinjalit për të përshkuar distancën satelit-përdorues, (shiko figurën 2.1). Duhet njohur pozicionet e të paktën 4 satelitëve për të bërë të mundur llogaritjen e pozicionit të GPS pranuesit (në këtë rast përcaktohen vlerat e gjatësisë, gjerësisë gjeografike, lartësisë si dhe kohës kur është llogaritur pozicioni) [18]. 


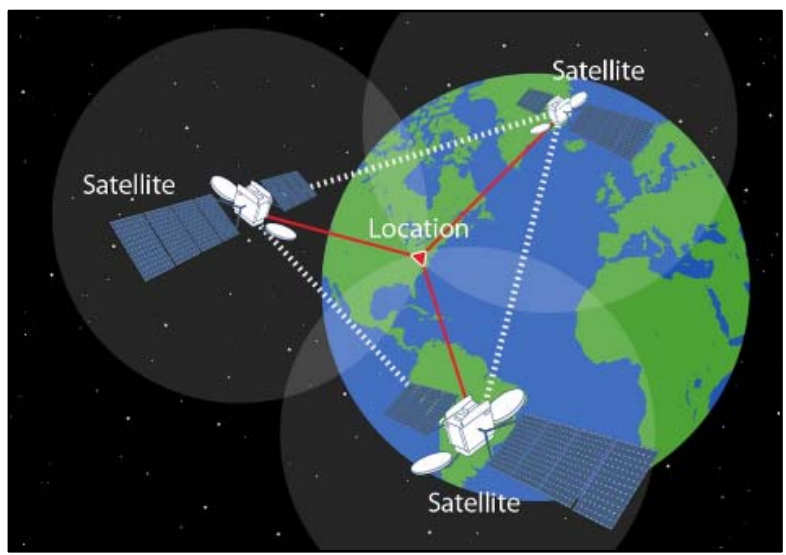

Figura 2.1. Parimi i funksionimit të GPS.

I tërë sistemi është i përbërë nga 27 satelitë, 24 në përdorim dhe 3 rezervë. Satelitët gjenden në një lartësi prej 19,000 km dhe udhëtojnë me shpejtësi 11,000 km/s [18].

Burime të mundshme të gabimeve në përcaktimin e pozicionit të një GPS pranuesi mund të jenë të ndryshme, si psh. ndikimi i jonosferës dhe troposferës, pranimi i sinjalit nga shumë drejtime (multipath), mossaktësia e clock-ut në GPS pranues, numri jo i mjaftueshëm i satelitëve në disponim, etj [18]. 


\subsection{GLOBAL SYSTEM FOR MOBILE COMMUNICATION - GSM}

GSM u prezantua për herë të parë në telefonat 2G. Është standardi i komunikimit më popullor në ditët e sotme për telefonat mobile. Sipas GSM Association $82 \%$ e tregut global mobile përdor GSM. GSM përdoret nga 3 miliardë njerëz në 212 shtete. Prezenca e tij mundëson shërbimin roaming midis operatorëve mobile. Në këtë mënyrë abonentët mund t’i përdorin telefonat e tyre pothuajse në çdo vend të botës. Ndryshimi nga paraardhësit e tij, GSM është tërësisht digjital. Prandaj edhe komunikimi i të dhënave në GSM është më i thjeshtë [1].

Lehtësimi i komunikimit të të dhënave lejoi që GSM të fus në përdorim shërbimin SMS (Short Text Messaging), Fax dhe transmetimin e të dhënave. Azhurimi i vitit 1997 i shtoi standartit aftësi për të paketuar të dhënat. Ky shërbim u quajt GPRS (General Packet Radio Service), ndërsa azhurimi tjetër i vitit 1999 solli shpejtësi më të lartë të transferimit të të dhënave duke përdorur EDGE (Enhanced Data Rates for GSM Evolution) [1].

$2 \mathrm{G}$ shërbeu si një punë revolucionare ku kjo teknologji siguroi një qartësim të zërit, dhe një shpejtësi transferimi deri ne $64 \mathrm{kbps}$. Pas kësaj erdhi teknologjia $2.5 \mathrm{G}$ ku arriti vetëm të rritë shpejtësinë deri në 144kbps [2].

Si avancim në teknologji erdhi $3 \mathrm{G}$ e cila si kusht kishte objektin video, dhe një shpejtësi shumë të lartë për transferimin e të dhënave deri në $3 \mathrm{Mbps}$, pas kësaj erdhi edhe avancimi në 3.5G i cili mundësoi shpejtësinë deri në 14.4 Mbps [4].

Në Europë termi 3G identifikohet nga UMTS (Universal Mobile Telecommunication System). Në Japoni dhe në SHBA sistemi 3G shpesh mban emrin IMT-2000 (International Mobile Telephony 2000). Ndonëse GSM është një sistem shumë i përhapur në të gjithë botën ai nuk mund të plotësojë të githa kërkesat në rritje të konsumatorëve për transmetim/marrje të dhënash me 
shpejtësi të lartë. Për të kaluar në UMTS është e nevojshme të kryhet një evolucion i arkitekturës së rrjetit bërthamë të GSM. Duke e përkufizuar si evolucion nënkuptohet që UMTS përdor të njëjtën arkitekturë thelbësore me GSM/GPRS/EDGE për shërbimet zanore dhe të të dhënave [5].

Teknologjia më tej është zhvendosur në 4G (WiMAX dhe LTE) ku ka bërë një zhvillim të lartë të videos, dhe siguroi një shpejtësi prej 100 Mbps. Tani teknologiia e cila pritet të hyjë në funksion është 5G ku ofron shpejtësi deri në $1 \mathrm{Gbps}$ [3].

Shumë shpejtë pasi filluan të përdoreshin rrjetat e para GSM në fillim të viteve 1990 u bë evidente se shërbimet e GSM (të cilët bazohen në shërbimet circuit-switched - këto shërbime bazohen në krijimin e qarqeve të transmetimit midis nyjeve që gjenden midis dy pikash transmetimi). Por këto nuk ishin shumë të përshtatshme për disa aplikacione që kanë natyrë shpërthyese (aplikacione që nuk e përdorin rrjetin gjithmonë me të njëjtin ritëm por në disa momente të caktuara mund ta përdorin në intensitet të vogël dhe në momente të tjera mund të shfaqin një ritëm të lartë përdorimi).

Sistemi GPRS i cili bën pjesë në brezin $2.5 \mathrm{G}$ dhe që është packet-switched ka kohë të shkurtër qasjeje në rrjet dhe tarifimi i shërbimit bazohet në sasinë e të dhënave të transmetuara. Me anë të GPRS është e mundur të komunikohet PTP (point-to-point) ose PTM (point-tomultipoint) [1]. 


\subsection{SISTEMI OPERATIV ANDROID}

Android është një sistem operativ i bazuar në Linux me një ndërfaqe të programimit Java. Android është krijuar nga Google dhe përdor një makinë të posaçme virtuale Machine Dalvik Virtual. Dalvik përdor bytecode të veçantë, prandaj bytecodet standarte të Javas nuk mund të ekzekutohen në Android. Android ofron një mjet "dx" që lejon kthimin e skedareve të Java klasëve në skedar "dex" (Dalvik executable). Aplikacionet Android janë të paketuara në një skedar .apk (Android Package). Për të thjeshtuar zhvillimin e programeve në Android, Google ofron Android Development Tools (ADT) [20].

Çdo aplikacion Android ekzekutohen si një proces në vete dhe sipas përdoruesit të tij. Prandaj aplikimi është i izoluar nga aplikacionet e tjera dhe një aplikacion tjetër nuk mund të dëmtoj lehtë aplikacionet e tjera Android. Si një diskutim i gjatë në një fushë të gjerë, nuk është vështirë të kuptohet pse ka pasur një konfuzion në lidhje me çfarë është me saktësi platforma Android. Android nuk është një implementim i Java ME për aplikacionet Android që janë të shkruara në gjuhën Java [20].

Aplikacionet nuk ekzekutohen në një makinë Java ME virtuale, dhe kompilimi i klasave të shkruara në Java nuk ekzekutohet vetvetiu në platformën Android. Android ka tanimë një histori të gjatë të versioneve të tij dhe versioni zyrtar aktual është "Oreo" i lëshuar në përdorim më 6 dhjetor 2017. Telefonat e mençur Android kanë të instaluar GPS pranues, me anë të të cilit mund të gjurmohet lehtësisht pozicioni aktual i vetë telefonit [20]. 


\subsection{SHËRBIMET E GOOGLE}

Google Inc. (Google.com) u themelua në vitin 1998 nga Larry Page dhe Sergey Brin të cilët e zhvilluan duke programuar makinën e kërkimit Google. Pas suksesit të madh të arritur, Google filloi ofrimin e shumë shërbimeve të tjera [21].

Një dekadë më parë hartat digjitale dhe përdorimi në masë i telefonave të mençur ndryshuan mënyrën se si ne navigojmë dhe udhëtojmë. Sot, telefonat dhe kompjuterat janë ata që na orientojnë në udhëtimet tona. Aplikacionet e ngjashme me Google Maps janë kthyer në një vegël shumë të rëndësishme për të gjithë njerëzit, e veçanërisht për ata që kanë humbur sensin e drejtimit [22].

Google Maps u lëshua për herë të parë në Shtetet e Bashkuara të Amerikës në 8 shkurt të vitit 2005 ku pasoi Mbretëria e Bashkuar dy vite më vonë. Me vonë gjatë vitit 2005 Google solli transportin publik dhe imazhet satelitore në këtë shërbim. Qëllimi i Google ishte të përfshinte botën në një hartë të vetme. Larry Page ka deklaruar se të dhënat dhe informacionet që shoqërojnë vendndodhje të ndryshme në hartë janë një element kyç në organizimin e infomacioneve për gjithë botën [22].

Në këtë punim shkencor janë përdorur hartat digjitale nga Google Maps për paraqitje vizuele të pozicioneve të autobusëve në kohë reale, llogaritjen e distancave në mes stacioneve dhe llogaritjen në kohë reale për arritjen e autobusëve tek stacioni përkatës. 
The distance matrix API është një shërbim që siguron distancën dhe kohën e udhëtimit nga pika fillestare deri në destinacion, ku është llogaritur distanca dhe koha në mes stacioneve dhe autobusit deri në destinacionin e dëshiruar e paraqitur brenda hartës të marrë nga Google Maps [23].

Geocoding API është shërbim i Google që bën konvertimin e adresave (psh. Rr.”Adem Ramadani") në koordinata gjeografike (latitude dhe longitude "42.662672, 21.164906"), si dhe për të shënjezuar pozicionimin në hartë [24].

The Geolocation API është shërbim i Google, që siguron lokacionin e pajisjes duke ekzekutuar aplikacionin në telefon të mençur, ku burimet e lokacionit merren përmes IP Adresës, Wi-Fi, Bluetooth MAC Address, RFID apo pajisjet me GPS dhe GSM/CDMA [25]. 


\subsection{SISTEME DHE HULUMTIME TË NGJAJSHME NGA LITERATURA DHE PRAKTIKA}

Hulumtimet, publikimet, dhe literatura mbi përcaktimin e trajektores lëvizëse së automjeteve, janë diskutuar gjerësisht në nivel akademik. Përcaktimi i trajektores lëvizëse në kohë reale dhe menaxhimi i automjeteve është një fushë me interes të veçantë për hulumtuesit, kështu që shumë studime janë iniciuar për të adresuar problemin e parashikimit të kohës së arritjes së automjeteve në kohë reale.

Revista e prezantuar nga El-Medany, W. dhe Al-Omary e përshkruan një sistem për përcaktimin e trajektores lëvizëse në kohë reale, që siguron pozicionet të sakta të automjetit me kosto të ulët. GM862 moduli është përdorur për implementim, një server për monitorim dhe një interface për përdoruesit në një webfaqe të zhvilluar nga Microsoft SQL Server 2003 dhe ASP.net për të parë lokacionin e automjetit në hartë. Poashtu, ofron informacion në lidhje me automjetin si shpejtësinë apo largësinë [9].

Hu Jian-ming, Li Jie dhe Li Guang-Hui përshkruajnë një sistem kundër vjedhjes së automjeteve duke përdorur GPS dhe GSM modulet. Sistemi është zhvilluar duke përdorur mikrokontrollerin C8051F120 dhe automjeti i vjedhur gjurmohet përmes senzorit. Sistemi informon pronarin e automjetit përmes GSM modulit, për sigurinë dhe besueshmërinë e automjetit $[10]$.

Fleischer, P.B. dhe Nelson përshkruajnë zhvillimin dhe vendosjen e GPS dhe GSM moduleve bazuar në përcaktimin e trajektores lëvizëse dhe sistemin e alarmit. Ky sistem lejon kompanitë e trafikut urban për përcaktimin e trajektores lëvizëse të automjeteve në kohë reale dhe ofron siguri nga vjedhjet e armatosura dhe ndodhitë e aksidenteve [11]. 
Le - Tien, T. Dhe Vu Phung përshkruajnë një sistem bazuar në GPS dhe GSM. Ky sistem është një model praktik për shtegun dhe përcaktimin e trajektores lëvizëse së automjeteve. Sistemi përmban dy senzorë YAS529 dhe KXSC72050 për të siguruar pozicionin e lëvizjes së automjetit. Sistemi i merr pozicionet e automjetit përmes GPS pranuesit dhe pastaj ato pozicione (koordinata) i dërgon te qendra menaxhuese me SMS ose GPRS. Përfundimisht, pozicioni i automjeteve gjatë lëvizjes do të shfaqet në Google Maps [12].

Moloo, R. K. dhe Digumber, propozuan një metodë për përcaktimin e trajektores lëvizëse të njeriut duke përdorur GPRS dhe GPS, ku kanë ulur koston e pajisjeve duke përdorur telefona të mençur që kanë GPS pranues në të dhe në vend të SMS-ëve duke përdorur GPRS për të komunikuar me Serverin. Një mobile aplikacion është zhvilluar për Android, që ka për qëllim që të gjurmojë vendndodhjen e GPS dhe të dërgojë ato pozicione përmes GPRS [13].

Sistemi për përcaktimin e trajektores lëvizëse të automjeteve ka qenë pjesë e sistemit Inteligjent të Transportit që nga viti 1970, por ishte e bazuar në hardware duke përdorur senzorë. Metodat për të marrë informata u përdorën nga një software në fund të viteve 1990, kurse në vitin 2000, përmes GPS-it, filloi gjetja e lokacionit të automjeteve në kohë reale. Shërbimi i trafikut urban në komunën e Prishtinës nuk është në kohë reale, pasi që ekziston orari i paracaktuar mirëpo mospërputhja e këtij orari me kohën reale të udhëtimit të cilën e përjetojnë qytetarët është shumë i madh. Pozicioni aktual dhe koha e parashikuar e arritjes së automjetit, qytetarëve i ofrohet nga Sistemi për përcaktimin e trajektores lëvizëse bazuar në GPS. Në lidhje me parashikim e kohës së arritjes, udhëtarët mund të vendosin të presin autobusin apo jo. Kjo ndihmon në marrjen e vendimeve më të mira për udhëtime nga ata. Nga ky sistem gjithashtu mund të përcaktohet nëse autobusi akoma nuk ka ardhur apo edhe tashmë veç ka shkuar. 
Pra, për ta bërë jetën më efikase, ky sistem ofron informacione të mjaftueshme. Për ta bërë trafikun urban më të përdorshëm, duhet të bëhet më i besueshëm dhe i saktë në kohë reale. Duke siguruar informacionet për kohën e arritjes së autobusëve përmes GPS, sistemeve të komunikimit pa tela si dhe sistemet tjera, vendet e zhvilluara e kanë bërë trafikun urban më të sigurt, më lehtë të parashikueshëm dhe menaxhueshëm [6].

Sistemi për përcaktimin e trajektores lëvizëse të automjeteve mund të klasifikohet në: Sistemin e bazuar në kohë reale dhe sistemin e parashikimit bazuar në eksperiencë (siç shihet në figurën 2.2.). Sistemi i bazuar në kohë reale (i realizuar në këtë punim shkencor) përdor vendndodhjen aktuale dhe shpejtësinë e automjetit për të llogaritur kohën e arritjes, kurse sistemi i parashikimit merr në konsideratë modelin e trafikut bazuar në eksperiencë për të llogaritur kohën e arritjes [6].

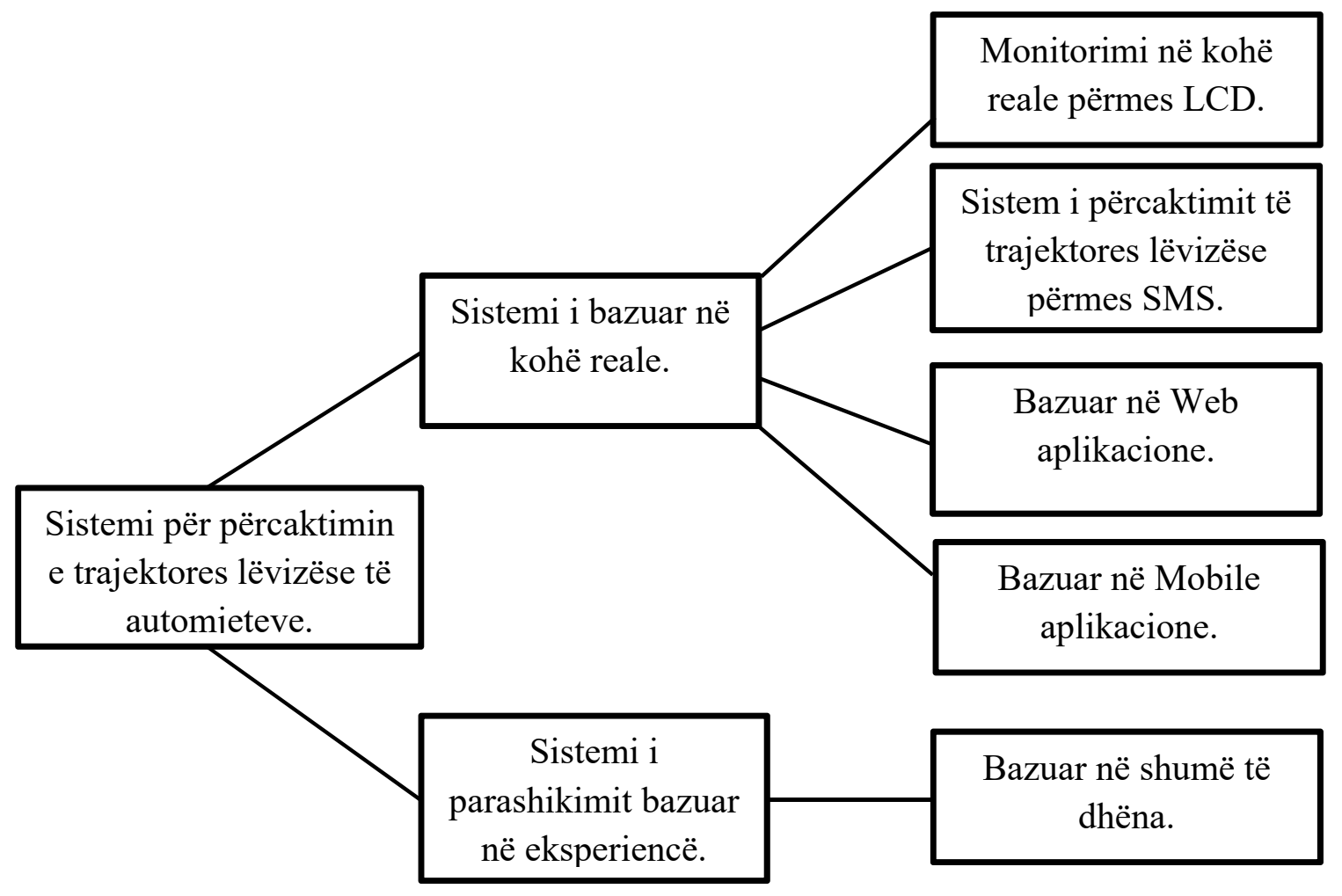

Figura 2.2. Metodat e sistemit të përcaktimit të trajektores lëvizëse së automjeteve. 
Sistemi i bazuar në kohë reale mund të klasifikohet si mëposhtë:

a) Monitorimi në kohë reale përmes LCD (Liquid Crystal Display) monitorëve.

b) Sistem i përcaktimit të trajektores lëvizëse përmes SMS (Short Message Service).

c) Bazuar në Web aplikacione, si dhe

d) Bazuar në Mobile aplikacion

Sistemet e bazuara në kohë reale për përcaktim të lokacionit mund të jenë edhe si sisteme të pavarura që tregojnë kohën e arritjes së automjeteve në ekranet LCD të vendosura në çdo stacion, nëpërmjet SMS-ve, web aplikacionit ose duke përdorur aplikacione për Android përmes GPRS. Modelet e bazuara në kohë reale janë përshkruar më poshtë [6].

Sistemet e bazuara në kohë reale përdorin ekranet LCD. Këto ekrane vendosën në çdo ndalesë (stacion), duke paraqitur kohën e arritjes së autobusit përmes transmetuesve RF (Radio Frekuencave). RF transmetuesit marrin sinjalet që përmbajnë koordinatat e GPS modulit të vendosur në çdo autobus. Lokacioni shfaqet në ekranet LCD së bashku me numrin (ID) e autobusit [14].

SMS përdoret përmes rrjetave GSM për të transferuar koordinatat e lokacionit të autobusit. Informacionet e lokacionit dërgohen tek serveri përmes rrjetave GSM duke përdorur SMS dhe pastaj ruhet në bazën e të dhënave. Udhëtari dërgon kërkesë dhe pranon informacionin përmes SMS [15]. 
Sistemi i bazuar në web aplikacion, ku përdoruesi mund të përcjell autobusin në mënyrë vizuale. Gjithashtu ky sistem i lejon përdoruerit në platforma të ndryshme (sisteme të ndryshme operative) ti qasen të dhënave të dëshiruara përmes Internetit. Përveq përcjelljes së autobusëve, ky sistem përmes hartave të Google mund të ndërveprojë me bazën e të dhënave për detalet $\mathrm{e}$ trajektores lëvizëse të automjeteve, që dmth. koordinatat e autobusit të përcjellur, përmes GPS pranuesit $\mathrm{i}$ pranon sinjalet e dërguara nga satelitët dhe përcakton pozitën e tij. Koordinatat dërgohen në server përmes shërbimit GPRS të rrjetit GSM si një paketë HTTP [16].

Sistemi për përcaktimin e trajektores lëvizëse të autobusëve duke përdorur mobile aplikacion e kanë shërbimin (pajisjen) GPS në telefonat e mençur për të përcaktuar koordinatat e tij. Këto koordinata të GPS dërgohen në Server. Përdoruesit mund të marrin informacione përmes Android aplikacionit [17].

Një tjetër metodë e sistemit të përcaktimit të trajektores lëvizëse së automjeteve bazohet në parashikimin e kohës së arritjes në bazë të eksperiencës, duke u bazuar në grumbullimin e shumë informatave të trafikut [6].

Nga të gjitha këto modele të bazuar në kohë reale, të përshkruara më lartë, në këtë punim shkencor është përdorur sistemi i bazuar në web dhe mobile aplikacion. 


\section{KOMPONENTËT E SISTEMIT}

\subsection{ARKITEKTURA}

Ideja e Sistemit Menaxhues të Trafikut Urban, është që të përcaktojë pozitën aktuale të autobusit në kohë reale dhe të llogaris distancën kohore të arritjes së autobusëve në stacione. Arkitektura e sistemit të propozuar është paraqitur në figurën e mëposhtme:

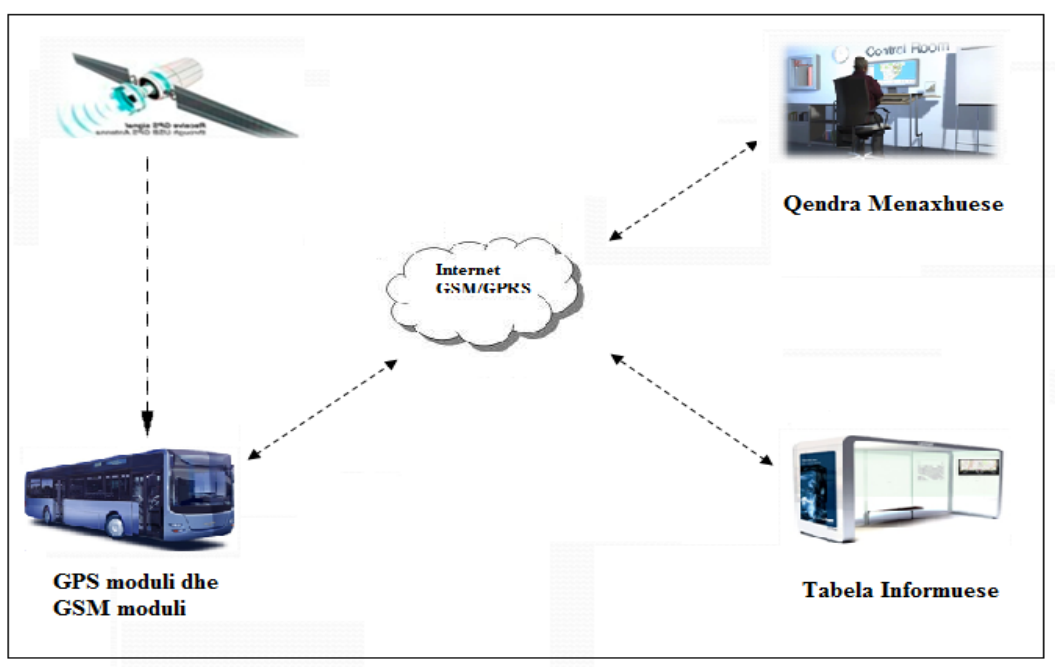

Figura 3.1. Arkitektura e Sistemit Menaxhues të Trafikut Urban.

Fillimisht bëhet pranimi i GPS sinjaleve nga GPS pranuesi dhe pastaj përcaktohet pozita e tij aktuale, gjegjësisht pozita e autobusit, dhe pastaj ky pozicion dërgohet tek Qendra Menaxhuese përmes GSM modulit. Qendra Menaxhuese (Serveri) përmban pozitën aktuale të lokacionit në formë të tabelave me informata kohore. Serveri i përpunon gjithashtu informatat e kërkuara nga udhëtarët rreth arritjes së autobusit në ndonjë stacion përkatës dhe e kthen këtë përgjigje duke përdorur web aplikacionin. 
Pra, Arkitektura e këtij sistemi, përbëhet nga tre module kryesore: GPS pranuesi dhe GSM moduli, Qendra Menaxhuese dhe Tabela Informuese.

\subsection{GPS PRANUESI DHE GSM MODULI}

Përcaktimi në kohë reale të pozitave të autobusëve (duke përdorur GPS sinjalet dhe duke i shfaqur ato në harta përmes shërbimit Google Maps) dhe koha e monitorimit fillon me GPS pranuesin, i cili pasi të ketë përcaktuar pozitën e tij, informatat naviguese $\mathrm{i}$ ofron në formë të NMEA (National Maritime European Asosiation) mesazheve. Ekzistojnë disa lloje të ndryshme të NMEA mesazheve psh. GGA, GLL, GSA, GSV, RMC etj., siç shihet në figurën 3.2. nga të cilat mund t'i marrim informata të ndryshme naviguese siç janë: koha, data, gjatësia dhe gjerësia gjeografike, lartësia mbidetare, numri i satelitëve që shihen, pozicioni i tyre apo shpejtësia me të cilën lëviz [26].

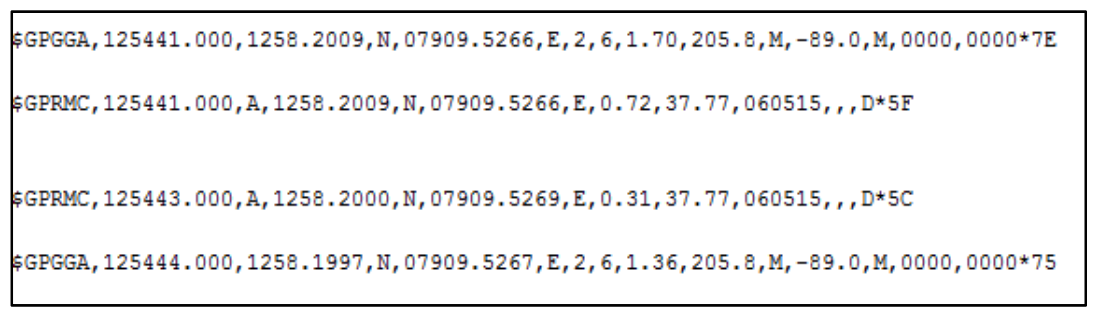

Figura 3.2. NMEA mesazh.

NMEA mesazhi "GGA”, përmban këtë format:

\$GPGGA, HHMMSS . SS, DDMM. MMMMM, K, DDDMM. MMMMM, L, N, QQ, PP . P , AAAA. AA, M, $\pm X X . X X, M, S S S, R R R{ }^{*} C C<C R><L F>$ 
Nga ky mesazh mund të nxjerren të dhënat më kryesore që nevojiten për përcaktimin e pozitës aktuale të autobusit në kohë reale:

\$GP - Identifikator që tregon se ky NMEA mesazh i takon GPS sistemit.

HHMMSS.SS - Koha kur është përcaktuar pozicioni në formatin orë, minuta dhe sekonda.

DDMM.MMMMM - Latituda (gjerësia gjeografike) në shkallë, minuta.

K - Treguesi i Latitudës që është N (veri) ose S (jug).

DDDMM.MMMMM - Longituda (gjatësia gjeografike) në shkallë, minuta.

L - Treguesi i Longitudës që është E (Lindje) apo W (Perëndim).

AAAA.AA - Altituda e shprehur në metra.

Ja një shembull konkret i një GGA mesazhi :

\$GPGGA,001038.00,3334.2313457,N,11211.0576940,W,2,04,5.4,354.682,M,26.574,M,7.0,013 8*79 


\subsection{QENDRA MENAXHUESE}

Serveri është vetë truri i Qendrës Menaxhuese të Sistemit Menaxhues të Trafikut Urban. Administratori është personi që menaxhon dhe monitoron tërë sistemin, siç është paraqitur më poshtë:

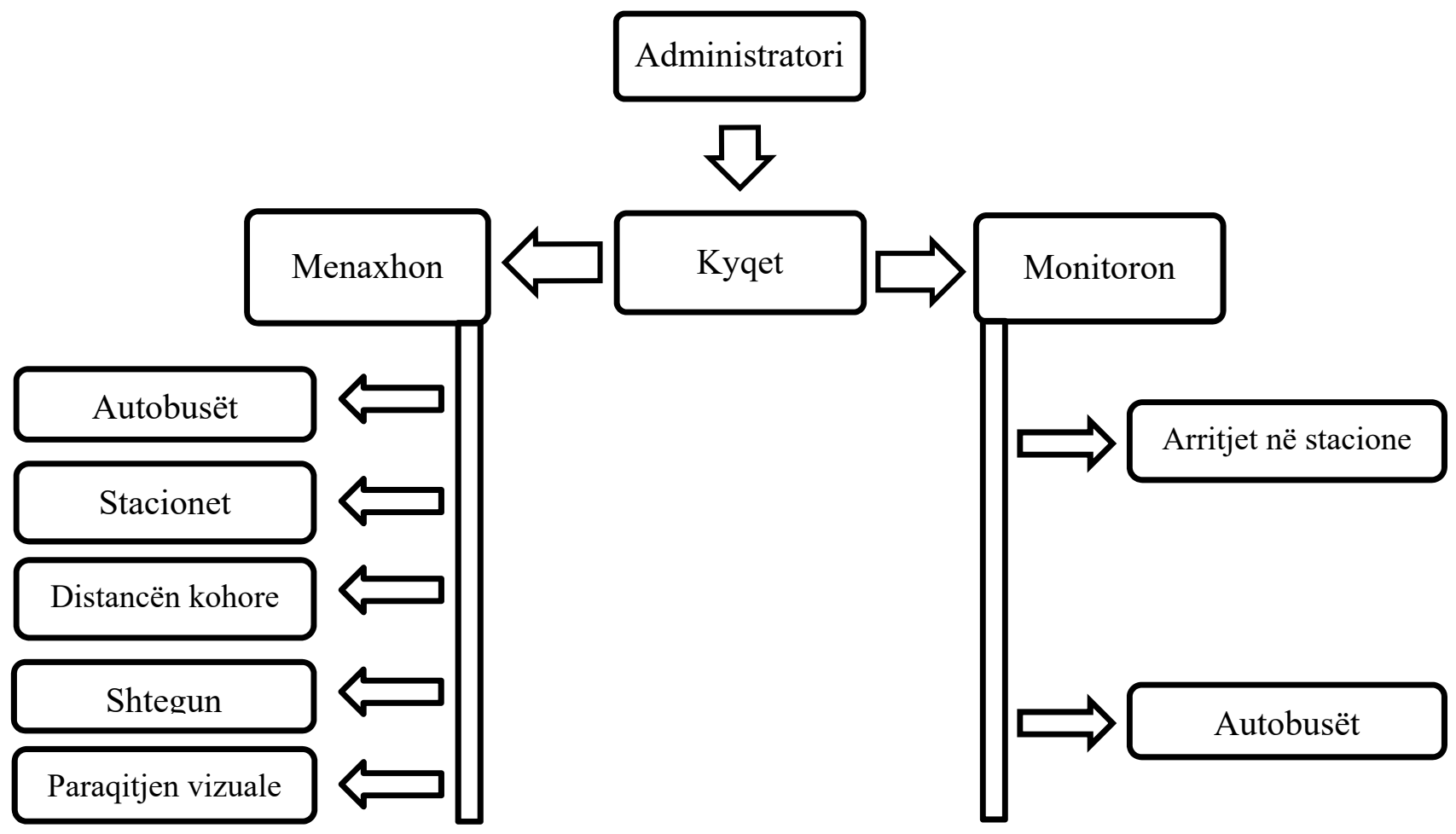

Figura 3.3. Rrjedha e të dhënave për Qendrën Menaxhuese.

Përveq koordinatave të dërguara nga GSM moduli, poashtu të dhënat tjera futen si rekorde në bazë të të dhënave. Vlerat e Latitudës, Longitudës, Latitudës të stacioneve që njëkohësisht paraqesin shtegun përkatës (pra pika e fillimit dhe mbarimit në mes dy stacioneve), të marra nga GPS moduli, janë të ruajtura paraprakisht në bazën e të dhënave poashtu. 
Duke i ditur këto koordinata, llogariten distanca në mes stacioneve, pra nga secili stacion përkatës deri te stacioni i ardhshëm.

Këto të dhëna llogariten vetëm njëherë dhe ruhen në fillim kur bëhet konfigurimi i sistemit, dhe ngaqë këto distanca nuk ndryshojnë atëherë mund të përdoren si të tilla në përcaktimin e distancës kohore deri tek stacionet e ardhshme.

Pra, koordinatat në kohë reale Latitude, Longitude, Altitude dhe koha, si dhe koordinatat e stacioneve përkatëse, shërbejnë për të llogaritur distancën kohore që autobusi duhet të arrij te stacioni përkatës apo edhe tek tjetri me radhë. 


\subsection{TABELA INFORMUESE}

Tek tabelat informuese shfaqen informatat në kohë reale për secilin stacion përkatës për kohën e arritjes së autobusëve. Tabelat informuese janë statike dhe jo interaktive. Ato thjeshtë paraqesin kohën se edhe sa minuta do të duhet të arrij autobusi në atë stacion. Mirëpo, sistemi ofron edhe tabela informuese dinamike, të cilat janë të qasshme përmes web aplikacionit. Përdoruesi mund të specifikojë se për cilin stacion dëshiron të shoh tabelën informuese. Kur kërkesa e tij dërgohet tek Serveri për të shfaqur kohën e arritjes së autobusit në stacionin përkatës, distanca kohore e llogaritur në Server, i dërgohet përdoruesit si përgjigje. Rrjedha e të dhënave e tabelës informuese te Sistemi Menaxhues i Trafikut Urban është paraqitur në figurën e mëposhtme:

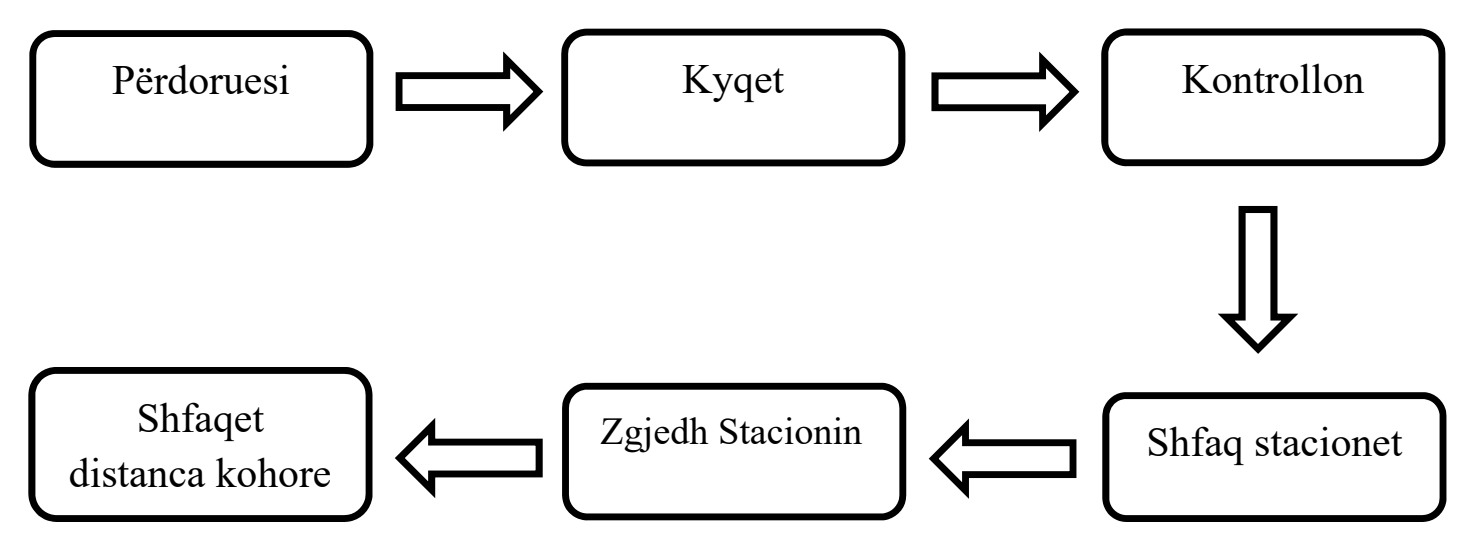

Figura 3.4. Rrjedha e të dhënave për tabelën informuese. 


\section{IMPLEMENTIMI I SISTEMIT}

Gjatë këtij punimi shkencor, për arsye financiare dhe kohore, kam përdorur mundësi tjera:

$>$ Një telefon të mençur me OS Android (Samsung Galaxy S4) për të simuluar GPS pranuesin dhe GSM modulin në kohë reale, duke supozuar që janë të instaluara në autobus.

$>$ Një laptop HP Pavilion dv5, i cili luan rolin e serverit dhe në të është i instaluar i tërë sistemi i Qendrës Menaxhuese, për menaxhimin dhe monitorimin e trafikut urban në khë reale.

$>$ Një telefon të mençur me OS Android (Samsung Galaxy Duos), që ka web shfletues për t’u njoftuar me distancën kohore të arritjes së autobusëve në stacione përkatëse, pra për të simuluar tabelën informuese.

Sistemi Menaxhues i Trafikut Urban ka këtë rrjedhë të të dhënave, siç shihet në fig. e mëposhtme:

$$
\text { GPS pranuesi përcakton pozicionet. }
$$

Pozicionet ruhen në një fajll (*.txt), për simulime të ndryshme.

GSM moduli dërgon pozicionet tek Web Serveri.

Severi i ruan të dhënat në bazën e të dhënave.

Serveri bën llogaritjet për kohën e arritjes së autobusëve tek stacionet e ardhshme dhe i ruan rezultatet në bazën e të dhënave.

Serveri i bën update hartës për autobusët dhe i shfaq në pozitë të re.

Figura 4.1. Rrjedha e të dhënave për tërë sistemin. 


\subsection{REALIZIMI}

Sistemi Menaxhues i Trafikut Urban është realizuar në këto tre procedura:

\section{1) Implementimi i mobile aplikacionit.}

\section{2) Implementimi i web serverit.}

\section{3) Implementimi i dy web aplikacioneve.}

Teknologjitë dhe mjetet e ndryshme që janë përdorur për realizimin e këtij sistemi, janë paraqitur më poshtë:

Android Studio Integrated Development Environment (IDE).

Android Software Development Kit (SDK).

Android Debugging Tool (ADT).

Windows 7.

$>$ Java.

Apache Web Server.

$>\mathrm{PhP}$.

$>$ Ajax.

$>$ MySQL.

$>$ HTML 5. 


\subsection{MOBILE APLIKACIONI}

Qëllimi i këtij aplikacioni është që të simulojë dhe të kryej funksionet e njëjta si të GPS pranuesit dhe GSM modulit të vërtetë që do të duhej të instaloheshin në autobus. Arsyeja pse kam zgjedhur OS Android si platformë, sepse është sistemi më i përdorshëm dhe më i adaptueshëm tani për tani. Aplikacioni është zhvilluar për të simuluar lëvizjet e autobusit në Trafikun Urban, për të përcaktuar dhe dërguar në kohë reale pozicionet (koordinatat) në server.

Po ashtu aplikacioni ka mundësi t’i ruaj pozicionet e simuluara në fajll tekstual (*.txt), që pastaj për teste të mëvonshme të përdoren ato pozicione reale të përcaktuara më parë. Aplikacioni merr nga GPS pranuesi këto informata naviguese Latitude, Longitude, Altitude dhe kohën, të cilave i bashkangjet edhe disa informacione tjera siç janë ID e autobusit, ID e linjës etj., dhe i dërgon si një mesazh të vetëm tek Qendra Menaxhuese. 


\subsubsection{NDËRVEPRIMI ME PËRDORUESIN}

Aplikacioni ka këtë interface, (siç shihet në figurën 4.2.) :

Fushën për paraqitjen e GPS koordinatave,

Dy mundësi zgjedhjeje, nëse pozicionet e përcaktuara duhet të ruhen ose nëse pozicionet e përcaktuara më herët do të simulohen tani.

$>$ Tre fusha të ndryshme për të definuar tre parametra, siç janë ID e Busit, ID e linjës dhe timeout (vonesat) në sekonda në rast të simulimit të pozicioneve, ose kohën ndërmjet dy pozicioneve reale të përcaktuara.

Dy butona për të filluar dhe ndaluar aplikacionin.

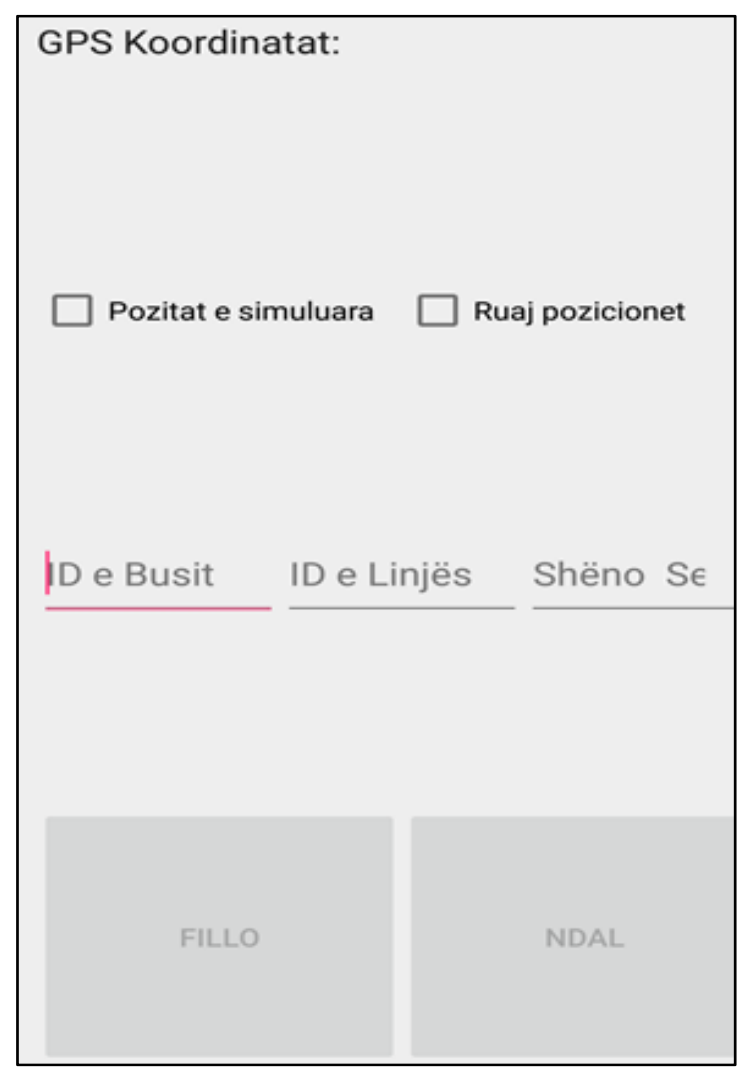

Figura 4.2. Mobile aplikacioni. 


\subsubsection{FUNKSIONIMI}

Aplikacioni i realizuar, ka tri mode të ndryshme të ekzekutimit:

$>$ Përcaktimi i koordinatave për herë të parë në kohë reale dhe ato të dërgohen menjëherë në Server.

Përcaktimi i koordinatave për herë të parë në kohë reale dhe ato të ruhen në një fajll tekstual (*.txt), që të mund të përdoren më pas për teste të ndryshme.

Simulimi i koordinatave të përcaktuara më herët dhe të ruajtura në tekstual file.

\section{Përcaktimi i koordinatave për herë të parë në kohë reale dhe dërgimi i menjëhershëm i tyre tek Qendra Menaxhuese, funksionon në këtë mënyrë:}

Fillimisht përdoruesi duhet të përcaktoj parametrat e kërkuara nga aplikacioni (ID e Busit, ID e linjës, Timeout në sekonda), për të filluar funksionin normal të tij, siç shihet në figurën 4.2. Pas përcaktimit të parametrave të mësipërm, përdoruesi duhet të startojë aplikacionin duke klikuar butonin FILLO. Nëse GPS pranuesi nuk është i aktivizuar, atëherë përdoruesit do t’i shfaqet një mesazh informues (shih figurën 4.3.), dhe kërkon nga ai që të bëjë aktivizimin e tij.

Aktivizimi i GPS pranuesit në mënyrë automatike përmes aplikacionit nuk është i mundur për shkaqe të privatësisë së përdoruesit. Në versionet e mëparshme të Androidit një gjë e tillë ka qenë e mundur, ndërsa në versionet aktuale ku privatësia e përdoruesit të telefonit të mençur luan një rol të veçantë, kjo veti nuk është e aplikueshme.

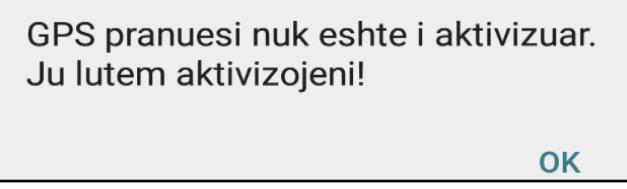

Figura 4.3. Mesazhi për aktivizimin e GPS. 
Në momentin që GPS pranuesi përcakton pozicionin në kohë reale, atëherë koordinatat (Latitude, Longitude, Altitude dhe koha) do të shfaqen në ekran (siç shihet në figurën 4.4.), dhe aplikacioni do të bëj azhurimin e koordinatave sipas sekondave të përcaktuara më lartë. Koordinatat e përcaktuara dërgohen përfundimisht tek Serveri përmes GSM modulit.

\begin{tabular}{l}
\hline GPS Koordinatat: \\
Time $=2018-06-0222: 52: 05$ \\
Latitude $=42.659290$ \\
Longitude $=21.160112$ \\
Altitude $=430$ \\
\hline
\end{tabular}

Figura 4.4. GPS Koordinatat e paraqitura në ekran.

> Përcaktimi i koordinatave për herë të parë në kohë reale dhe ruajtja e tyre në një fajll tekstual (*.txt), qё të mund të përdoren më pas për simulime të ndryshme, funksionon në këtë mënyrë:

Fillimisht përdoruesi duhet të përcaktoj të dhënat e kërkuara nga aplikacioni, për të filluar funksionin normal të tij, siç shihet në figurën 4.2. Për ti ruajtur koordinatat e përcaktuara në një fajll tekstual (ku ID e autobusit, përdoret tek emri i fajllit tekstual psh. autobusi me ID numër 2, do të ruhet me këtë emër tek fajlli tekstual bus2.txt) dhe ato të mund ti përdorim pastaj për teste të ndryshme, përdoruesi duhet të zgjedh opsionin Ruaj pozicionet (shiko figurën 4.2.)

Pas përcaktimit të parametrave të mësipërm, përdoruesi duhet të startojë aplikacionin duke klikuar butonin FILLO. Nëse GPS pranuesi nuk është i aktivizuar, atëherë përdoruesit do t’i shfaqet një mesazh informues (shih figurën 4.3.), dhe kërkon nga ai që të bëjë aktivizimin e tij. 
Në momentin që GPS pranuesi përcakton pozicionin në kohë reale, atëherë koordinatat Latitude, Longitude, Altitude dhe koha do të shfaqen në ekran (siç shihet në figurën 4.4.), dhe aplikacioni do të bëj azhurimin e koordinatave sipas sekondave të përcaktuara më lartë. Koordinatat e shfaqura në ekran (Latitude, Longitude, Altitude) do të ruhen si fajll tekstual te follderi Documents (tek shtegu i përcaktuar My Files $>$ Local Storage $>$ Device storage $>$ Documents) në telefon të mençur, siç shihet në figurën 4.5.:

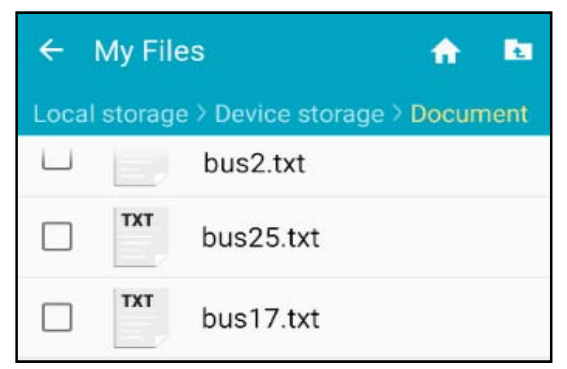

Figura 4.5. Fajllat tekstual me koordinata të ruajtura në telefon të mençur.

Koordinatat e përcaktuara nga GPS pranuesi përmes GPS sinjaleve të pranuara të cilat dërgohen nga satelitët, do të ruhen në fajll tekstual në këtë renditje Latitude, Longitude dhe Altitude të ndarë me presje (shiko figurën 4.6.).

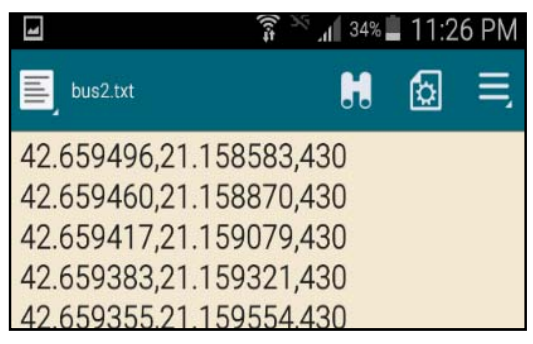

Figura 4.6. Koordinatat (Latitude, Longitude, Altitude) të ruajtura në fajll. 
Simulimi i koordinatave të përcaktuara më parë dhe të ruajtura në fajllin tekstual, që mund të përdoren për teste të ndryshme, funksionon në këtë mënyrë:

Fillimisht përdoruesi duhet të përcaktoj të dhënat e kërkuara nga aplikacioni, mirëpo tashmë duhet të përcaktoj vetëm ID e Busit dhe ID e Linjës, për të filluar simulimin nga fajlli tekstual, ku përmes ID së autobusit mund të zgjedhim fajllin e dëshiruar për të simuluar pozicionet e përcaktuara më parë. Për ti simuluar koordinatat e ruajtura në fajll tekstual, përdoruesi duhet të zgjedh opsionin Pozitat e simuluara, (shiko figurën 4.2.)

Pas përcaktimit të parametrave të mësipërm, përdoruesi duhet të startojë aplikacionin duke klikuar butonin FILLO. Nëse përdoruesi dëshiron të ndalojë përcaktimin e koordinatave, atëherë duhet të klikoj butonin NDAL (siç shihet në figurën 4.2.).

Për të evituar, ndonjë gabim të paqëllimshëm dhe ndaljen e aplikacionit pa dëshirë, përdoruesi do të pyetet edhe njëherë nëse ai me të vërtetë dëshiron ta ndalojë atë (shih figurën 4.7.)

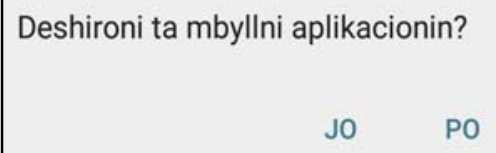

Figura 4.7. Mesazhi për të mbyllur mobile aplikacionin. 


\subsection{WEB SERVERI}

Në këtë pjesë është përshkruar Web Serveri dhe implementimi e tij, i cili përdoret për t’i ruajtur dhe menaxhuar koordinatat e dërguara në kohë reale. Përmes phpMyAdmin është krijuar MySQL baza e të dhënave për të gjithë sistemin dhe testet e tij.

Krijimi i bazës së të dhënave dhe tabelave në web server:

Në Localhost është krijuar baza e të dhënave e quajtur "transpub" që ka këto tabela: actualdistance, coordinate_bus, paraqitja_vizuele, stacionet, tab_lines, siç është paraqitur në figurën e mëposhtme:

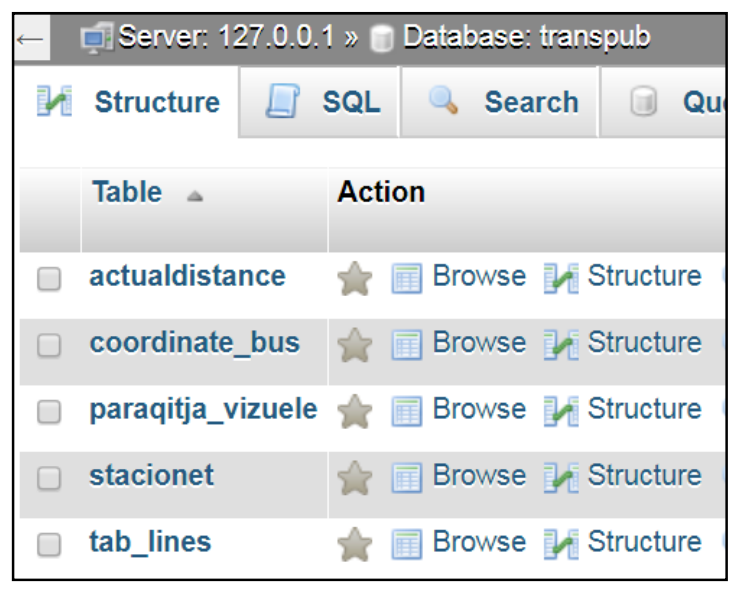

Figura 4.8. Baza e të dhënave me tabela.

Në bazën e të dhënave do të ruhen të dhënat (koordinatat në kohë reale të Autobusit) të dërguara nga GSM moduli. Poashtu, disa të dhëna janë ruajtur në mënyrë statike, si psh. koordinatat për paraqitje vizuale të shtegut lëvizës të autobusëve, koordinatat e stacioneve dhe autobusët qe kalojnë nëpër linja të caktuara. 
Në tabelën Stacionet janë të ruajtura të dhënat statike: emrat e stacioneve dhe linjaID. Pra ato linja qe kalojnë nëpër stacione përkatëse me koordinata (Latitude, Longitude dhe Altitude) të atyre stacioneve të marrë nga hartat e Google (Google Maps), siç shihet në figurën 4.9.:

\begin{tabular}{|r|l|r|r|r|r|}
\hline id & emri linjald & latitude & longitude & altitude \\
\hline 1 & Sta1 & 4 & 42.673338 & 21.198213 & 430 \\
\hline 2 & Sta2 & 4,5 & 42669146 & 21.190577 & 430 \\
\hline 3 & Sta3 & 4,5 & 42.6657 & 21.183466 & 430 \\
\hline 4 & Sta4 & 4,5 & 42.666036 & 21.180331 & 430 \\
\hline
\end{tabular}

Figura 4.9. Tabela stacionet.

Në tabelën Tab_lines janë të ruajtura të dhënat statike për linjat që kalojnë nëpër stacione përkatëse si dhe distanca kohore ndërmjet dy stacioneve të marrë nga shërbimet e Google (The distance matrix API), siç shihet në figurën 4.10.:

\begin{tabular}{|c|c|c|c|}
\hline id & lineld & stationsids & duration \\
\hline 1 & 4 & $1,2,3,4,5,6,7$ & $1.75,1 \cdot 26,0.45,0,9,1 \cdot 3,0.35$ \\
\hline 2 & 5 & $2,3,4,5,6,7,20,21,22,12,13,14,15,16,17$ & $1.26,0,45,0.9,1,3,0,35,188,0,71,1,28,2.66,2.06,1$ \\
\hline 3 & 1 & $23,24,22,25,26,27,28,29,30,31$ & $4.38,1.95,1.21,0.6,4.76,1.93,0.33,1.95,4.36$ \\
\hline 4 & 500 & $38,39,40,41,42$ & $0.93,1.41,1,38,1.05$ \\
\hline 5 & 7 & $48,47,35,25,26,49,50,51.52$ & $0.35 .231,338.0 .6,176,371,1.83,1.76$ \\
\hline
\end{tabular}

Figura 4.10. Tabela tab_lines.

Në tabelën Paraqitja_vizuele janë të ruajtura koordinatat statike (Latitude, Longitude), pra linjat e udhëtimit, për t’i paraqitur ato me ngjyra të caktuara, siç është paraqitur më poshtë:

\begin{tabular}{|r|r|l|l|}
\hline id & linjald & color & $\begin{array}{l}\text { koordinatat } \\
\text { Jane Lattuda.Longtuda te Linjes te ndara me pikepresje }\end{array}$ \\
\hline 1 & 4 & $\# 0000 \mathrm{FF}$ & $42.673737,21.199219 ; 42.673662,21.198951 ; 42.671522, \ldots$ \\
\hline 2 & 1 & $\# F F 0000$ & $42.648907,21.167619 ; 42.649341,21.166547 ; 42.649625, \ldots$ \\
\hline 3 & 5 & $\# 36 \mathrm{c} 100$ & $42.668970,21.190116 ; 42.668217,21.188544 ; 42.667625, \ldots$ \\
\hline
\end{tabular}

Figura 4.11. Tabela paraqitja_vizuele. 
Në tabelën Coordinate_bus janë të ruajtura koordinatat në kohë reale që dërgohen përmes GSM modulit për koordinatat e secilit autobus, (të paraqitur në figurën 4.12). Pra të dhënat e përcaktuara nga mobile aplikacioni në momentin që është bërë i mundur përcaktimi i pozicionit (BusID, lineID, time, latitude, longitude dhe altitude).

\begin{tabular}{|r|r|r|l|r|r|r|}
\hline id $>1$ & buslD & linelD & time & \multicolumn{1}{l|}{ latitude } & longitude & altitude \\
\hline 25610 & 15 & 4 & $2017-10-2300: 25: 40$ & 42.66701515 & 21.174504383333332 & 628.2 \\
\hline 25609 & 15 & 4 & $2017-10-2300: 25: 39$ & 42.667008333333335 & 21.174548383333335 & 628.2 \\
\hline 25608 & 18 & 500 & $2017-10-2300: 25: 42$ & 42.6673032 & 21.172631066666668 & 630.8 \\
\hline 25607 & 15 & 4 & $2017-10-2300: 25: 38$ & 42.66700095 & 21.17459505 & 627.5 \\
\hline
\end{tabular}

Figura 4.12. Tabela coordinate_bus.

Në tabelën Actualdistance ruhen distancat kohore në mes stacioneve, ku fillimisht llogaritja e distancës në kohë nga pozicioni aktual tek stacioni i ardhshëm (TimeToStations dhe nextStationID), si dhe për stacionet në vazhdim e deri tek stacioni i fundit (lastDistances), siç është paraqitur në figurën e mëposhtme:

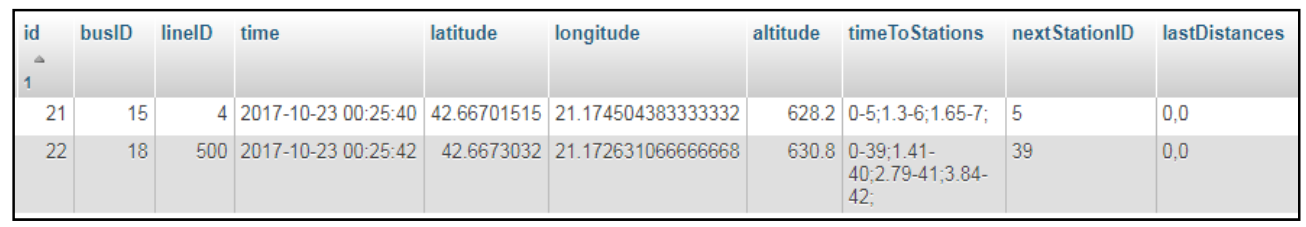

Figura 4.13.Tabela actualdistance.

Pastaj, përmes query-t tek tabela actualdistance, bëhet llogaritja e distancës deri tek stacioni i parë i ardhshëm, apo edhe deri tek stacioni i fundit. Momentin që autobusi kalon stacionin e destinuar, fillon llogaritja kohore për stacionin tjetër të ardhshëm, e kështu me radhë deri tek stacioni i fundit, siç është shënuar me ngjyrë të kuqe tek figura 4.14.

\begin{tabular}{|c|c|c|c|c|c|c|c|}
\hline busID & lineID & time & latitude & longitude & altitude & timeToStations & nextStationID \\
\hline 15 & 4 & $2017-10-2300: 25: 40$ & 42.66701515 & 21.174504383333332 & 628.2 & $0-5 ; 1.3-6 ; 1.65-7$; & 5 \\
\hline 18 & 500 & $2017-10-2300: 25: 42$ & 42.6673032 & 21.172631066666668 & 630.8 & $\begin{array}{l}0-39 ; 1.41- \\
40 ; 2.79-41 ; 3.84- \\
42\end{array}$ & 39 \\
\hline
\end{tabular}

Figura 4.14. Llogaritja e distancave. 


\subsection{WEB APLIKACIONI}

Sistemi menaxhues përmban dy web aplikacione. Njëri për të paraqitur hartat digjitale (të marra nga shërbimi i Google Maps), si dhe gjithë autobusët që janë të kyqur në sistem, gjithë stacionet e regjistruara dhe trajektoret e secilës linjë në transportin publik, kurse tjetri për tabelën informuese, për informimin e qytetareve në kohë reale për kohen arritjes së autobusëve në stacione përkatëse.

Web aplikacioni për menaxhimin dhe monitorimin e këtij sistemi, do të përdoret nga administratori, i cili ka autorizim të plotë për menaxhimin e sistemit si psh. të shtoj, ndryshoj, të editoj dhe të fshij të dhënat për autobusët, linjat, stacionet dhe paraqitjen vizuale.

Paraqitja vizuale e web aplikacionit përmban:

Hartën e qytetit - për monitorimin e autobusëve në kohë reale vizualisht, siç shihet në figurën e mëposhtme.

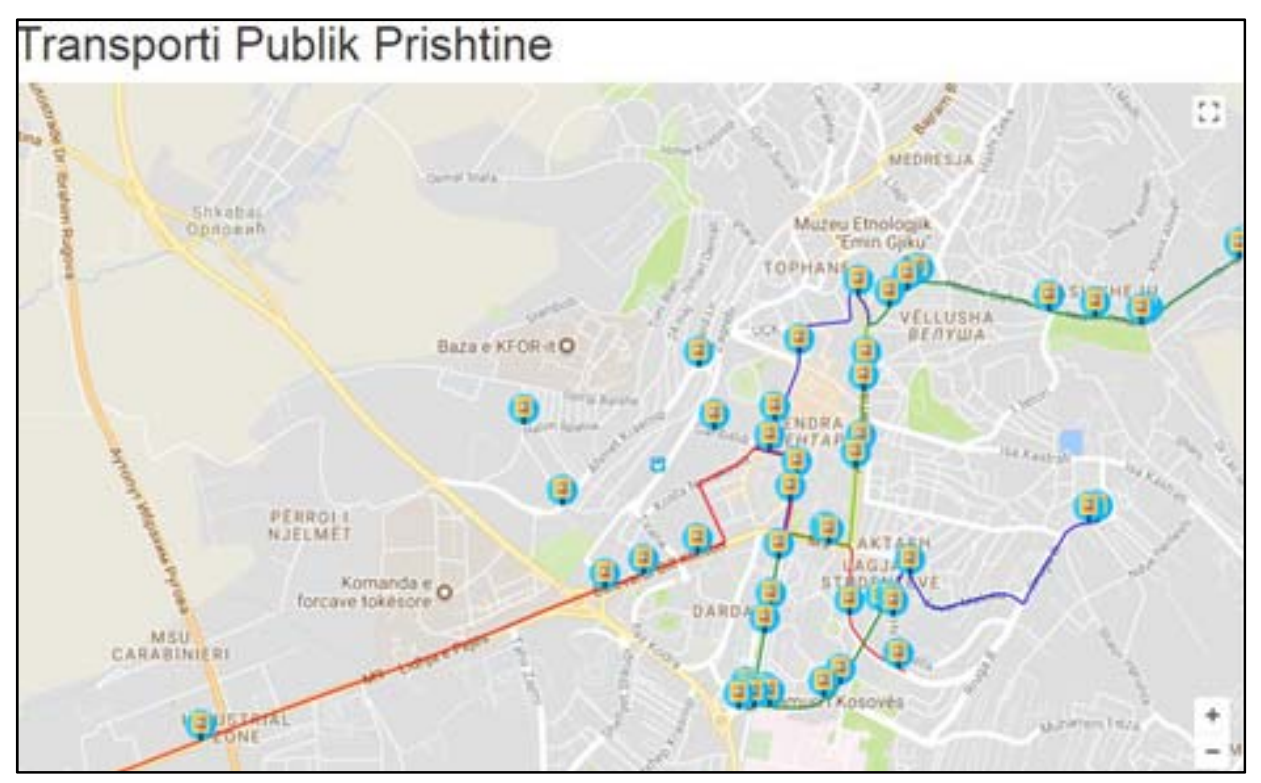

Figura 4.15. Harta e qytetit të Prishtinës. 
Autobusët - monitoron dhe kontrollon arritjet e autobusëve në stacione përkatëse, siç është paraqitur më poshtë:

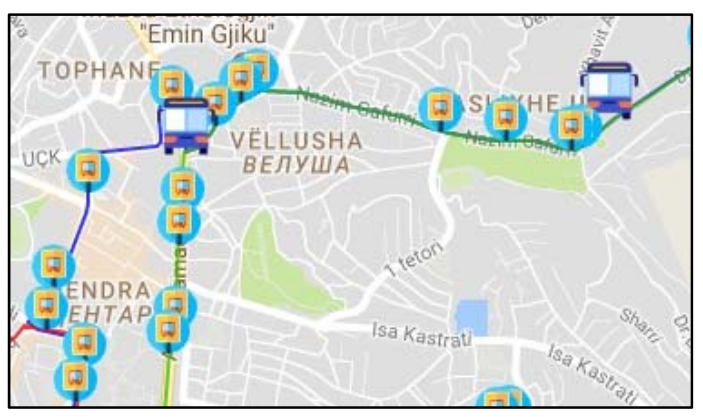

Figura 4.16. Autobusët në hartë.

Emrat e stacioneve të autobusëve - administratori kontrollon dhe Stacionet përkatëse sipas emërtimit dhe arritjet e autobusëve në ato stacione, siç shihet më poshtë:

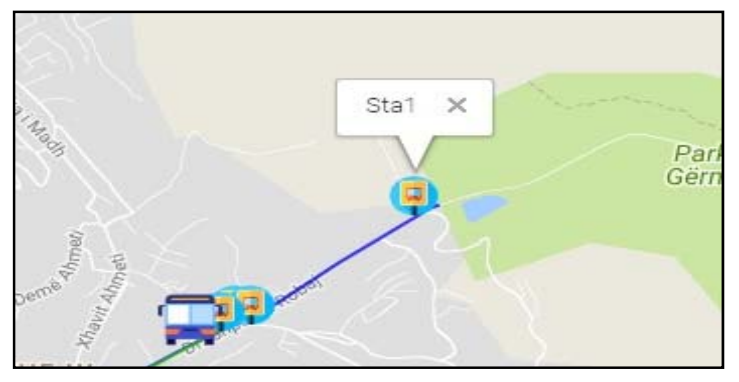

Figura 4.17. Emrat e stacioneve në hartë.

ID Busit, Linjës, Stacionin e ardhshëm dhe kohën - gjatë lëvizjes së autobusit, administratori mund të kontrollojë sipas ID-ve të paraqitura, ku poashtu mund të monitorojë dhe kohën e arritjes së autobusit në stacionin e ardhshëm, siç është paraqitur në figurën 4.18.

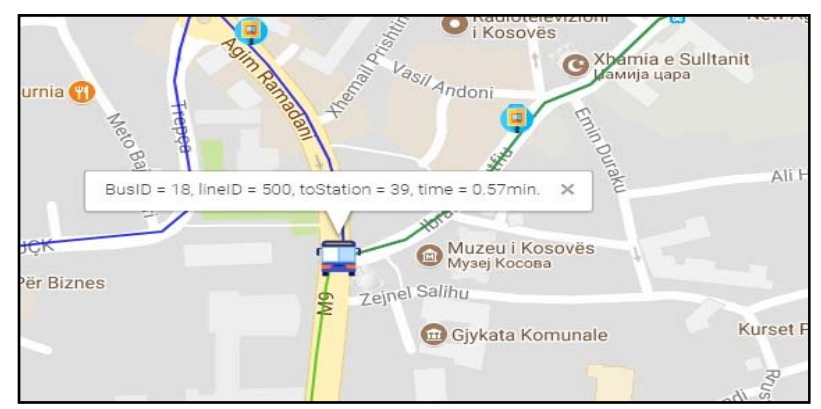

Figura 4.18. ID e busit, linjës, stacioni i ardhshëm dhe koha e arritjes në stacion së autobusit. 
Siç është përmendur dhe më lartë, web aplikacioni i dytë është dedikuar për tabelat informuese që do të bëjnë informimin në kohë reale për kohën e arritjes së autobusëve në stacionet e dëshiruara. Secila tabelë ka një ID identifikuese, ku i merr të dhënat (distancën kohore) nga Serveri dhe i publikon në secilën tabelë informuese. Është i qasshëm për qytetarët përmes Internetit.

Pra, fillimisht përdoruesi (qytetari) duhet të zgjedh stacionin e dëshiruar për të parë distancën kohore deri në arritjen e autobusit në stacion. Për shembull, në stacionin 42, autobusi me ID 18, linja 5, arrin edhe 4.41 minuta, siç shihet në figurën 4.19.

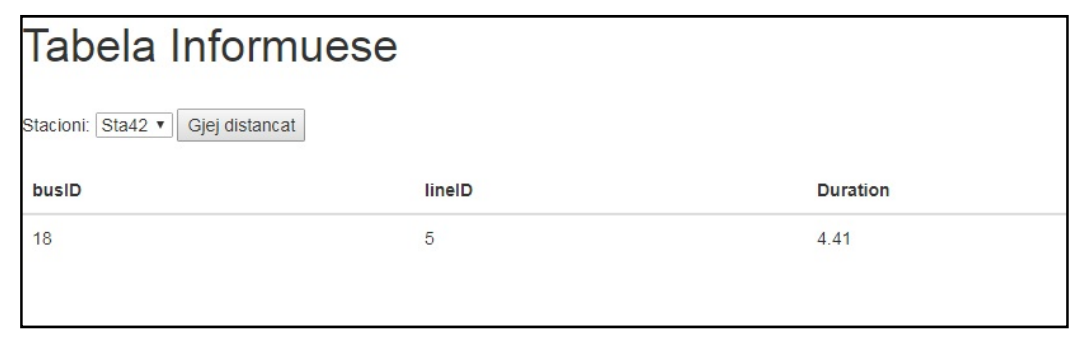

Figura 4.19. Tabela informuese për stacionin 42.

Nëse përdoruesi zgjedh një stacion që në ato momente nuk ka autobus që shkon në atë drejtim, si për shembull në Stacionin 3 nuk kemi ndonjë autobus që do kalojë në këtë stacion për një kohë të caktuar, atëherë shfaqet mesazhi i tillë, siç shihet në figurën e mëposhtme.

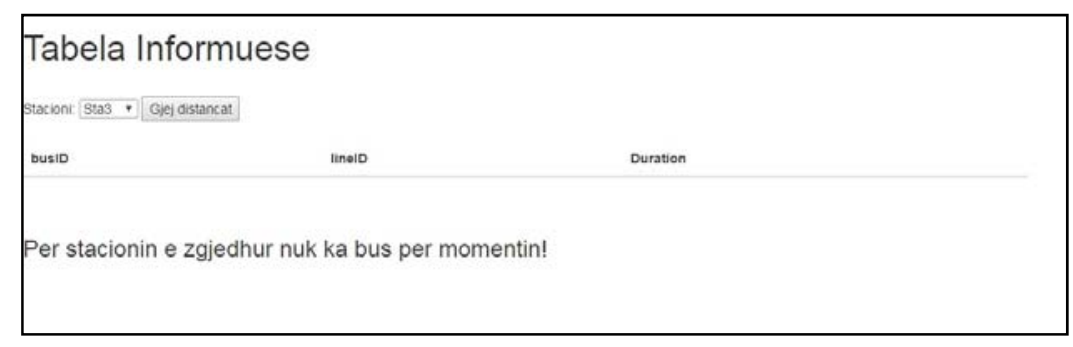

Figura 4.20. Tabela informuese për stacionin 3. 


\section{TESTIMI DHE REZULTATET}

Në këtë kapitull, është vlerësuar dhe analizuar përformanca e Sistemit Menaxhues të Trafikut Urban në bazë të rezultateve dhe krahasimeve të bëra në mes tyre, kohën e arritjes së autobusëve në stacione përkatëse, pozicionin aktual te secilit autobus, si dhe përformancën e web aplikacioneve. Për t’i përditësuar koordinatat në kohe reale, është shumë me rëndësi matja me saktësi e pozicioneve dhe dërgimi i tyre përmes GSM modulit.

\subsection{TESTIMI}

Testet janë bërë në qytetit e Prishtinës, siç shihet në figurën 5.1. përkatësisht:

Në Linjën 1 - që kalon nga Fakulteti Teknik e deri në Fushë-Kosovë (paraqitur me ngjyrë të kuqe), Në Linjën 4 - që kalon nga Bregu i Diellit e deri në Gërmi (paraqitur me ngjyrë të kaltër), $N$ ë Linjën 5 - që kalon nga AUK (Universiteti Amerikan) e deri tek Tregu i Gjelbër (te Bregu i Diellit), (paraqitur me ngjyrë te gjelbër).

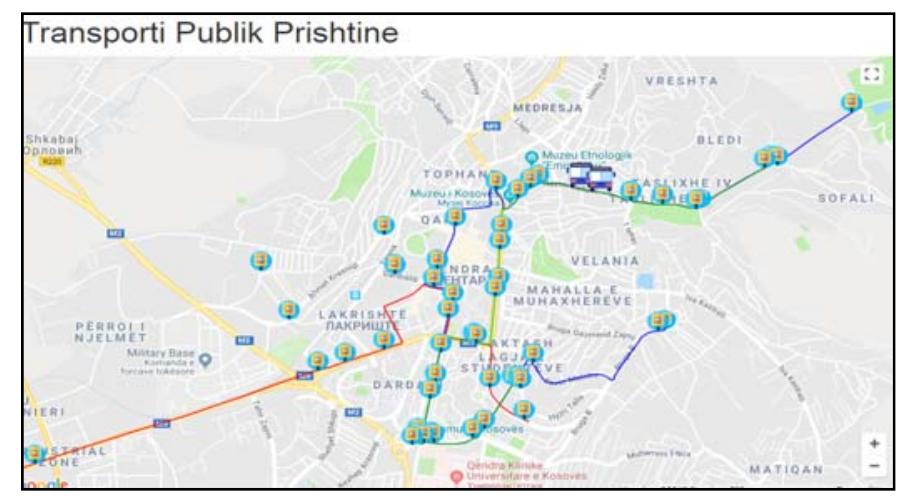

Figura 5.1. Linja 1,4,5 të paraqitur në hartë (të dalluara me ngjyra).

Testet janë realizuar në Trafikun Urban në qytetin e Prishtinës, ku simulimi i pozicioneve është bërë përmes një telefoni të mençur (Samsung Galaxy S4). Koordinatat janë përcaktuar për çdo sekondë dhe janë ruajtur në fajlla tekstual përkatës në telefon, ku pastaj gjatë testeve të ndryshme koordinatat janë dërguar përmes GSM modulit në Server. 


\subsection{REZULTATET}

Më poshtë kam paraqitur disa rezultate (koordinata) të përcaktuara nga GPS pranuesi gjatë simulimit të linjës 4 , siç shihet në figurën e mëposhtme:

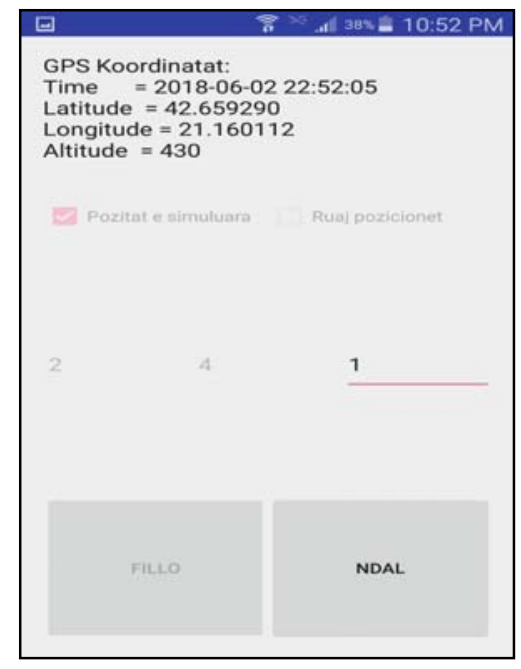

a) Koordinatat e përcaktuara gjatë testimit.

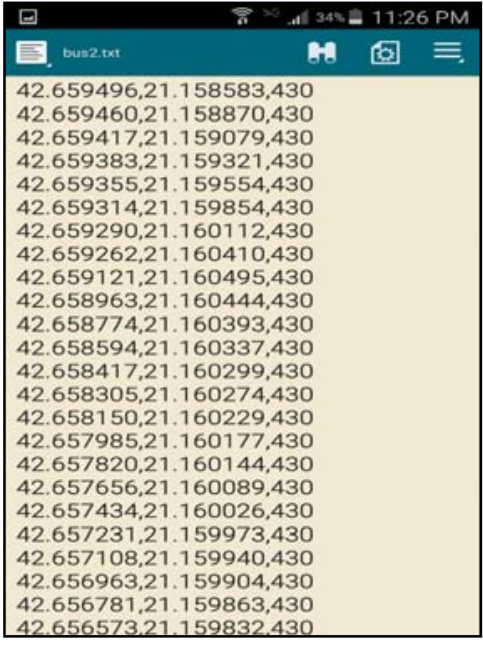

b) Koordinatat e përcaktuara të ruajtura në fajll.

Figura 5.2. Koordinata të përcaktuara nga GPS pranuesi.

Koordinatat e përcaktuara nga GPS pranuesi, përgjatë testeve të realizuara në linjën 4 dhe 5 (shih figurën 5.3.), të dërguara në Server përmes GSM modulit, ku më pastaj Serveri i përpunon këto informata në kohë reale, duke i paraqitur vizualisht në hartë.

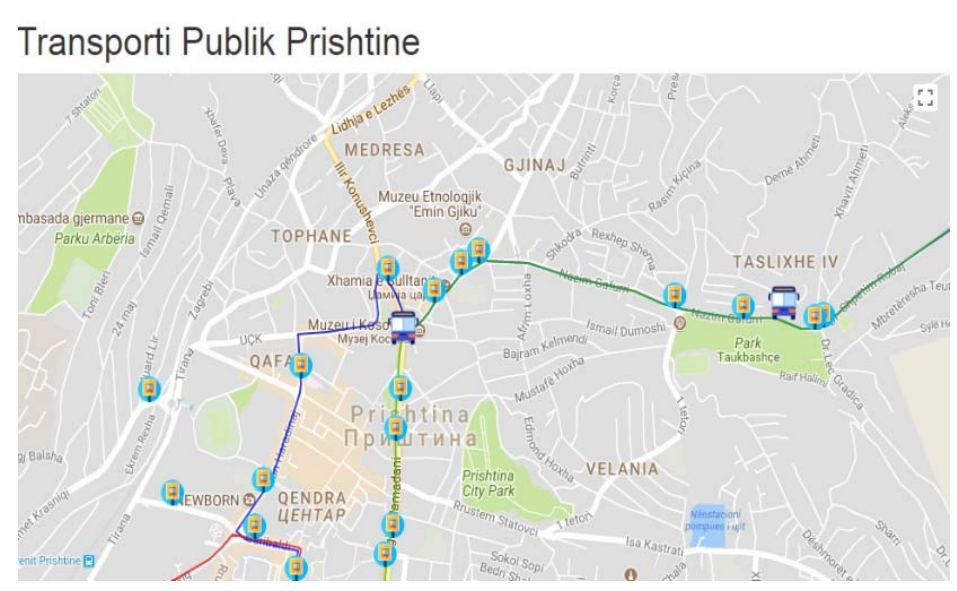

1. Bus ID $=2$, lineID $=4$, to Station $=4$, time

$=0.25 \mathrm{~min}$.

2. Bus $I D=18$, linelD $=5$, to Station $=39$, time $=0.62 \mathrm{~min}$.

Figura 5.3. Paraqitja vizuale e pozicioneve në kohë reale të autobusëve në hartë. 
Disa gabime që kemi vërejtur gjatë matjeve dhe testimeve, kanë qenë këto:

Mungesa e disa rrugëve në hartën e qytetit të Prishtinës, që nuk janë integruar në hartat e Google Maps, siç është paraqitur me ngjyrë të kuqe në figurën 5.4., që në të vërtetë ekziston kjo rrugë, por mungon përmirësimi në hartë i kësaj rruge.

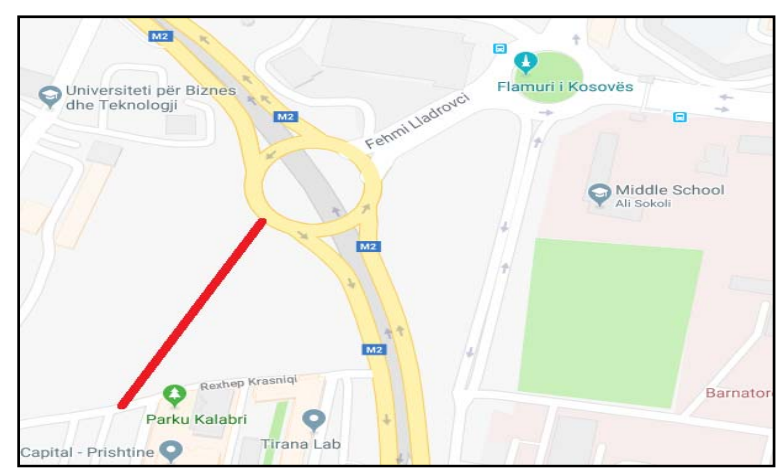

Figura 5.4. Gabime në hartat e Google.

$>\quad$ Devijimet e GPS pranuesit në telefon të mençur (toleranca e gabimit) në përcaktimin e saktë të koordinatave janë vërejtur gjatë analizimit të rezultateve poashtu, gjë që nuk e ka saktësinë e duhur në disa vende, gabimet janë diku 3 metra larg rrugës, siç është paraqitur në figurën 5.5.

Kjo mossaktësi në përcaktimin e pozicionit aktual ka si shkak disa prej burimeve të gabimeve të mundshme të përmendua në kapitullin 2.1 .
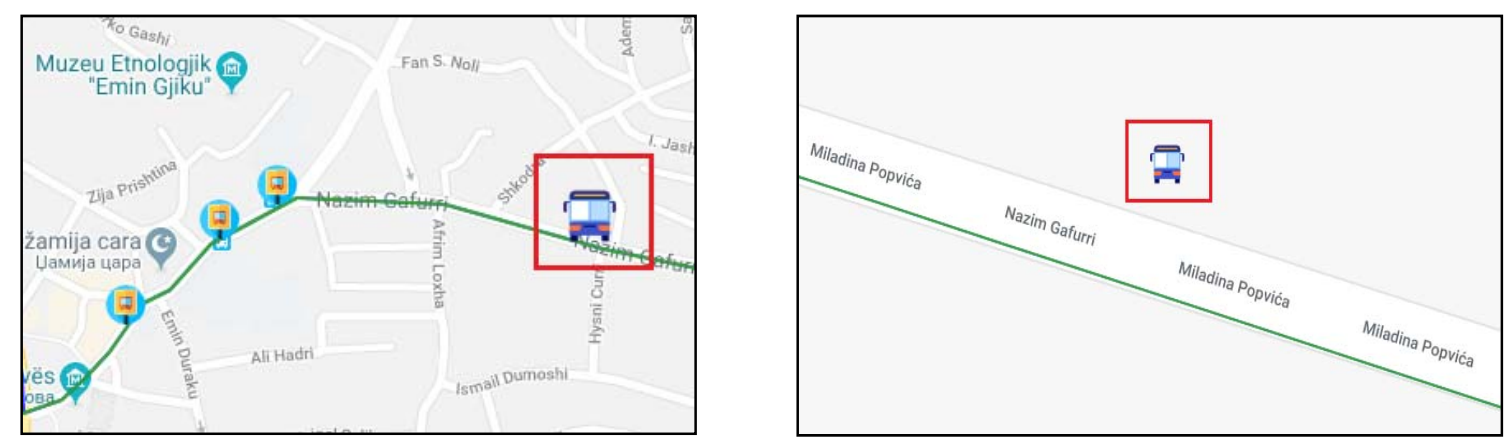

Figura 5.5. Devijimi i GPS pranuesit në telefon të mençur. 


\section{KONKLUZIONET DHE MUNDËSITË}

\subsection{KONKLUZIONET}

Duke parë që sistemi i propozuar, i testuar dhe i analizuar ka pasur një performancë solide, mund të konkludohet që lehtë mund të implementohet në Trafikun Urban në qytetit e Prishtinës.

Është përshkruar në detaje implementimi i këtij prototipi, së bashku me gjithë pjesët përbërëse të tij siç janë mobile aplikacioni, web serveri dhe web aplikacionet.

Telefoni i mençur që është përdorur për përcaktimin e koordinatave të autobusëve në kohë reale dhe dërgimin në Web Server, lehtë mund të zëvendësohet (implementohet) me një GPS pajisje dhe GSM modul duke e vendosur në secilin autobus, me një kosto jo shumë të madhe.

Web aplikacioni i përdorur mund të zgjerohet në të ardhmen edhe në më shumë funksione duke parë dhe mundësitë e zgjerimit të Trafikut Urban si psh. vonesat e shoferëve në çdo stacion që shkon, apo dhe nëse rrugët do të jenë të bllokuara dhe nëse ka vonesa të mëdha.

Kurse për tabelën informuese, gjatë testimeve që kemi përdorur telefon të mençur mund të implementohet lehtësisht në çdo stacion nga një TV që ka LAN Interface ose WLAN ose GSM modul si dhe një web shfletues (browser) për shfaqjen e te dhënave (distancën kohore). Gjithashtu, secili qytetarë duke përdorur Internetin, nga çfarëdo lokacioni të ketë qasje tek tabela informuese (përmes një webfaqeje) për stacionet dhe autobusët përkatës dhe arritjen e tyre në kohë reale. 


\subsection{MUNDËSITË}

Gjatë analizave dhe hulumtimeve, është vërejtur se sistemi mund të zgjerohet dhe të avancohet në të ardhmen. Një tjetër hulumtim shkencor mund të bëhet duke bërë teste përgjatë një muaji, çdo ditë, dhe në periudha kohore të ndryshme për disa nga linjat më kryesore në Trafikun Urban të Prishtinës. Pastaj ato teste të realizuara në bazë të eksperiencës psh. gjatë kohës së pushimit të drekës nga dita e Hënë deri të Premten (ora 12:00 - 13:00) kemi trafik shumë të ngarkuar, kurse shërbimi i Google The distance matrix API, shfaq informacione rreth kohës së arritjes në kushte normale.

Nga këto matje dhe teste që do bëhen, do të mund të bëjmë një analizë dhe të provojmë të jemi më të saktë në kohë reale sesa kohën e arritjes që e marrim të gatshme nga shërbimi i Google The distance matrix API psh. nga testi që është bërë (nga ora 12:00 deri 13:00) që pika e fillimit ishte PTK (Posta dhe Telekomunikacioni i Kosovës) e deri tek Hotel Grand, kemi vërejtur se shërbimi i Google The distance matrix API na jep kohën e arritjes për 6 minuta në kushte normale (Shiko figurën 6.1.), kurse në bazë të eksperiencës ne kemi bërë 20 minuta deri në destinacion.

Mund të konstatojmë se çdo ditë e kemi fluksin e njejtë, prandaj duke bërë një hulumtim shkencor në bazë të eksperiencës dhe duke krahasuar me kohën që na jep shërbimi i Google The distance matrix API, mund të provojmë të jemi më të saktë në llogaritje kohore në krahasim me distancën kohore që na ofron ky shërbim i Google në kushte normale. 


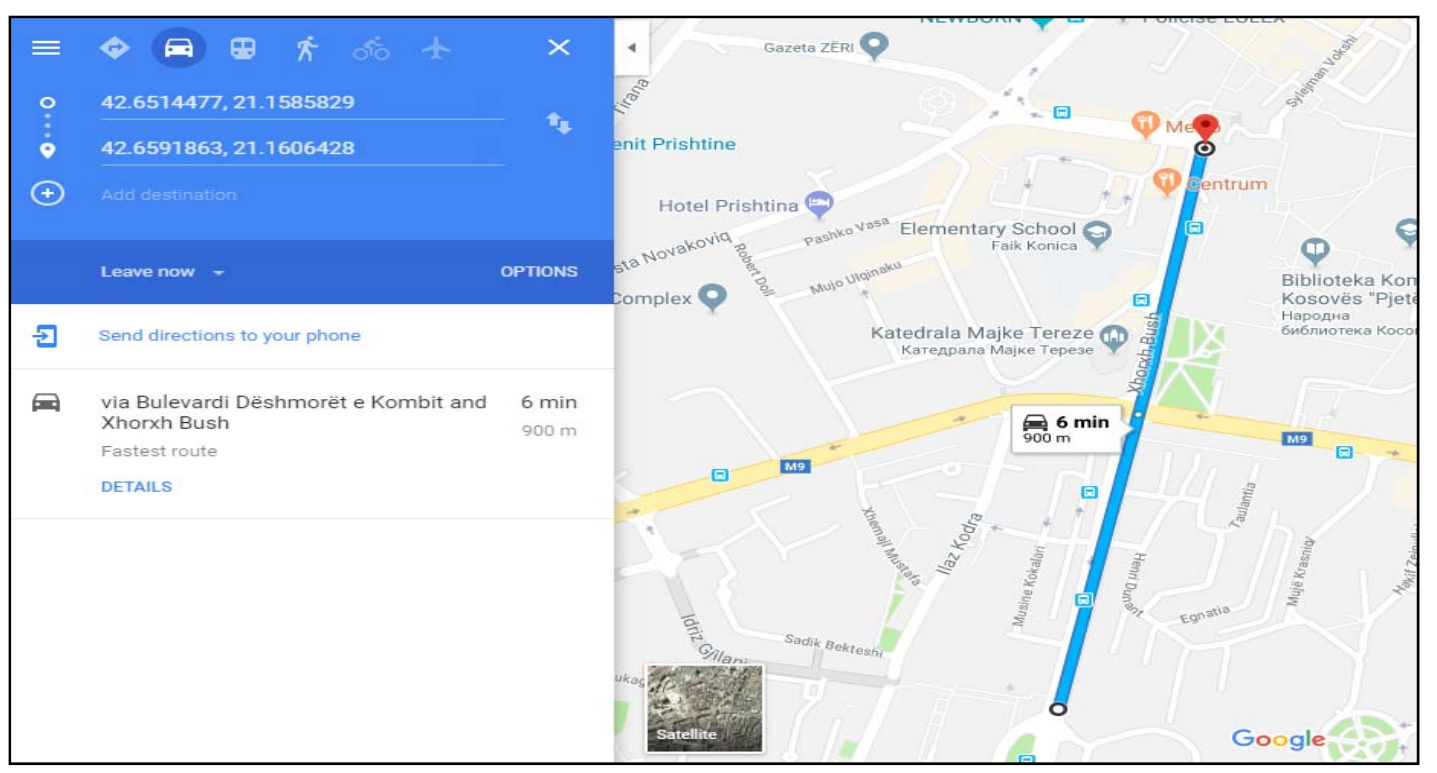

Figura 6.1. Distanca kohore nga shërbimi i Google The distance matrix API. 


\section{LITERATURA}

[1] J. Schiller, Mobile Communications. Addison-Wesley, 2000.

[2] P. S. Akhilesh Kumar, Technology, 2012.

[3] N.B.A. Aryaputra, 5G - The Future of Mobile Network, 2011.

[4] X. Li, A. Gani, The Future of Mobile Wireless Communication, 2009.

[5] Jay R Churi, Evolution of Networks 2G-5G, 2012.

[6] Ejaz Qayyum, Zeeshan Mohsin, Junaid Malik, Real-time Vehicle Tracking System Using GPS \& GSM, 2013.

[7] H. Sundmaeker, P. Guillemin, P. Friess, S. Woelfflé, Vision and Challenges for Realizing the Internet of Things, European Commission Information Society and Media, March 2010.

[8] K. Ashton, That 'Internet of Things' Thing, RFID Journal, 22 June 2009.

[9] El-Medany,W.;Al-Omary,A.;Al-Hakim,R.;Al-Irhayim,S.;Nusaif,M.,"A Cost Effective RealTime Tracking System Prototype Using Integrated GPS/GPRS Module," Wireless and Mobile Communications (ICWMC), 2010 6th International Conference on,vol.,no.,pp.521,525,20-25

Sept.2010.

[10] Hu Jian-ming; Li Jie; Li Guang-Hui, "Automobile Anti-theft System Based on GSM and GPS Module," Intelligent Networks and Intelligent Systems (ICINIS), 2012 Fifth International Conference on , vol., no., pp.199,201, 1-3 Nov. 2012 
[11] Fleischer, P.B.; Nelson, A.Y.; Sowah, R.A.; Bremang, A., "Design and development of GPS/GSM based vehicle tracking and alert system for commercial inter-city buses," Adaptive Science \& Technology (ICAST), 2012 IEEE 4th International Conference on , vol., no., pp.1,6, 25-27 Oct. 2012

[12] Le-Tien, T.; Vu Phung-The, "Routing and Tracking System for Mobile Vehicles in Large Area,"Electronic Design, Test and Application, 2010. DELTA '10. Fifth IEEE International Symposium on , vol., no., pp.297,300, 13-15 Jan. 2010

[13] Moloo, R. K., \& Digumber, V. K. (2011, July). Low-cost mobile GPS tracking solution. In Business Computing and Global Informatization (BCGIN), 2011 International Conference on (pp. 516-519).IEEE.

[14] Gunjal Sunil N. , Joshi Ajinkya V., Gosavi Swapnil C. , Kshirsagar Vyanktesh B, “Dynamic Bus Timetable Using GPS” International Journal of Advanced Research in Computer Engineering \& Technology (IJARCET), ISSN :2278-1323, Volume 3, Issue 3, March 2014.

[15] Karan Punjabi, Pooja Bolaj, Pratibha Mantur, Sneha Wali, "Bus Locator via SMS Using Android Application" International Journal of Computer Science and Information Technologies (IJCSIT), ISSN :0975-9646, Volume 5(2), 2014.

[16] Manini Kumbhar, Meghana Survase, Pratibha Mastud, Avdhut Salunke,Shrinivas Sirdeshpande, "Real Time Web Based Bus Tracking System" International Research Journal of Engineering and Technology (IRJET), e-ISSN: 2395 -0056 Volume: 03 Issue: Feb-2016. 
[17] Mr. Pradip Suresh Mane, Prof. Vaishali Khairnar, "Analysis of Bus Tracking System Using Gps on Smart Phones” IOSR Journal of Computer Engineering (IOSRJCE), ISSN: 2347-8586, Vol.3, Issue 3, 2015, Page.1057-1061.

[18] http://e-rashica.weebly.com/uploads/2/7/4/0/27402083/ligjerata_6.pptx, vizituar më 06.06.2018.

[19] http://www.fti.edu.al/data/pages/47/attach/phd alban rakipi implementimi dhe testimi i alg oritmit_raim.pdf, vizituar më 05.04.2018.

[20] http://mobile.geo.edu.al/wp-content/uploads//Platforma-Android.pdf, vizituar më 17.04.2018.

[21] https://www.google.com/about/our-story/, vizituar më 21.05.2018.

[22] http://pcworld.al/google-maps-nje-dekade-transformimi-te-hartave-dixhitale/, vizituar më 10.04.2018.

[23] https://developers.google.com/maps/documentation/distance-matrix/intro, vizituar më 13.05.2018.

[24] https://developers.google.com/maps/documentation/geocoding/intro, vizituar më 01.06.2018.

[25] https://www.w3.org/TR/geolocation-API/, vizituar më 04.04.2018.

[26] https://hemispheregnss.com/gnssreference/GPGGA.htm, vizituar më 01.04.2018. 